\title{
Price discrimination and the modes of failure in deregulated retail electricity markets
}

\author{
Paul Simshauser *a
}

\begin{abstract}
In Australia, as with Great Britain, governments have shown rising concern with the health of competitive residential electricity markets. A core concern is the practice of price discrimination and the rising dispersion of prices. The State of Queensland deregulated its residential electricity market in 2016 when almost simultaneously, the two jurisdictions that pioneered this reform, Great Britain and Victoria, were questioning their prior policy decision. Queensland makes for a fascinating case study because Southeast Queensland comprises a fully deregulated retail market while Regional Queensland is a regulated monopoly - with common input costs across both zones. Consequently, a regulated monopoly with a uniform tariff and 640,000 customers forms a very large control group, which can be directly compared to the competitive market of more than 1.3 million customers - making such analysis globally unique. Analysis of Queensland market conditions concludes the policy is welfare enhancing, and that British and Victorian concerns regarding price discrimination practices are misguided. To be clear, rising electricity prices are a problem, but price discrimination is not. The deregulated competitive market is, perhaps unsurprisingly, better at regulating the overall average tariff and consumer welfare has been enhanced by $\$ 184$ million per annum - with some consumer segments very materially better off. However, certain modes of failure remain, viz. an inter-consumer misallocation problem and lack of transparency vis-à-vis the anchoring of discounts - known as the "discounts off what?" problem. The former is currently trivial, and the latter requires further research.
\end{abstract}

Keywords: Price discrimination, electricity prices, jawboning.

\section{Introduction}

When contestability commences in the mass market segment of a retail electricity market ${ }^{1}$, prices commence a natural drift from a regulated and uniform (two-part) tariff to discriminatory prices - this arises in energy markets due to the policy design of vesting incumbent retailers with a default tariff, and contestability arising via rival retailer discounts (see Giulietti et al. 2005; IPART, 2013; Simshauser, 2014; Waddams Price \& Zhu, 2015; Littlechild, 2016; Waddams Price \& Zhu, 2016; He \& Rainer, 2017; Nelson et al. 2018; Flores \& Waddams Price, 2018). A market progression of rival entry, greater product complexity and price dispersion is common in former regulated capital-intensive monopoly industries such as telecommunications, airlines and energy as Borenstein \& Rose (1994), Dana (1998, 1999b), Levine (2002), Baumol \& Swanson (2003), Littlechild (2014) and Simshauser \& Whish-Wilson (2017) explain. Thus, while regulated retail price caps are initially retained as a proxy safety-net for inactive small consumers as the market shifts from single monopoly provider to competitive market, the regulated default tariff or "Standing Offer" forms a price-to-beat. Rival and new entrant retailers entering a franchise service area will offer discounts off the incumbent's Standing Offer tariff in order to poach customers. Incumbents are forced to construct their own discounted matching-products in response. Discounts off a Standing Offer tariff and associated price dispersion are thus a central design feature of a fully contestable retail electricity market.

\footnotetext{
* Professor of Economics, Griffith Business School, Griffith University. Views expressed in this article are those of the author.

Associate, Energy Policy Research Group, University of Cambridge.

${ }^{1}$ To ensure an orderly transition, competition in retail electricity markets occurs progressively with a timetable comprising 4-6 Tranches of consumers spanning a 4-8 year window. In Great Britain, retail market contestability started in the early-1990s with the residential market made contestable in 1999, and price controls removed in 2002 (Littlechild, 2016). In the NEM contestability varied by region, viz: Victoria 1994-2002, New South Wales 1996-2002; Queensland 1998-2007, South Australia 1998-2003. Price controls in these NEM regions were removed in 2009, 2014, 2016 and 2013 respectively.
} 
Considerable evidence exists to suggest the success of Full Retail Contestability is inextricably linked to expected gains from switching supplier. Gains to residential consumers are most visibly expressed as a "percentage discount off $\mathrm{f}^{2}$ " the existing Standing Offer tariff. This rivalrous process hinges critically on the existence of the Standing Offer, from which discounted products are anchored.

When the mass market is deemed workably competitive the requirement for an independent regulator to set a regulated Standing Offer price cap no longer exists. Incumbent retailers who retain an obligation to supply ${ }^{3}$ in their former franchise area - must ensure a Standing Offer tariff (and associated default levels of service) is available at all times. The critical difference pre- and post-price deregulation is that incumbent retailers are free to select the price-to-beat. As Littlechild (2017) explains, this residential market liberalisation template was largely pioneered by Great Britain (1999) and the Victorian (2002) region of Australia's National Electricity Market (NEM).

When retail prices are deregulated, all things being equal the number of rival suppliers will expand rapidly because key business risks (i.e. regulatory risk, regulatory mistakes, dynamic inconsistency) have, at least in theory, been removed. ${ }^{4}$ Consequently, an incumbent retailer will not only encounter traditional incumbent rivals from adjacent service areas, but additional new entrant " $2^{\text {nd }}$ Tier" retailers. Starting without a franchise customer base, $2^{\text {nd }}$ Tier retailers accumulate customers based on various customer-focused strategies such as low-cost, on-line or renewable energy models.

Energy retailers further segment consumer groupings well beyond coarse historic segments of Commercial \& Industrial, Small Business and Residential. Sophisticated retailers might dissect Residentials into six or more sub-segments, for example, 1) affluent urban professionals, 2) budget conscious families, 3) pensioners, 4) socially conscious households; 5) time-poor families; and 6) tech-savvy households. Products, product bundles and marketing channels to market are specifically constructed to target customers in these discrete sub-segments. Furthermore, some households have solar PV, and/or controlled load (i.e. ripple control) associated with swimming pool pumps and hot water systems. Each metering combination requires discrete product bundles.

Consequently, with the number of retailers expanding, consumer sub-segments multiplying, and the mix of discrete household metered loads rising, the number of products necessarily proliferates. Product proliferation is driven by customer needs and competitive intensity, i.e. retailers design products to attack rivals, and to defend their own customers from competitor poaching.

As Queensland was removing price controls in 2016, Victoria and Great Britain, the jurisdictions which pioneered Full Retail Contestability and price deregulation, were investigating whether to reinstate the price controls that Queensland was removing. The British regulator (Ofgem) had instigated various formal market investigations and policy constraints from 2008 before handing the problem to the British Competition and Markets Authority (see Ofgem, 2008, 2011; Littlechild, 2016b; CMA, 2016). Victoria established a formal inquiry into the efficacy of its deregulation policy (Thwaites et al. 2017) and the Commonwealth Government initiated a formal review of retail electricity markets (ACCC, 2017).

\footnotetext{
${ }^{2}$ British research revealed only $19 \%$ of consumers preferred wanted to stop discounts being expressed in percentage terms ( $c f$. dollar savings). In addition, he strongest driver of customer activity is the size of anticipated gains from switching - not the simplicity of offers available. See Littlechild (2014) for details. See also Giulietti et al. (2005), IPART (2013), Simshauser (2014), Littlechild (2014), Waddams Price \& Zhu (2015), Littlechild (2016), Waddams Price \& Zhu (2016), He \& Rainer (2017), Flores \& Waddams Price (2018).

${ }^{3}$ This is usually a condition of their retail licence.

${ }^{4}$ As one Reviewer noted if market prices are rising this may prevent profitable entry.

${ }^{5}$ Heard (2017) argues that there are three tiers with $2^{\text {nd }}$ Tier Retailers being highly successful new entrants (many of which have also vertically integrated) while the $3^{\text {rd }}$ Tier represents the boutique sub-scale new entrants.
} 
At the core of policymaker concerns in both countries were the evolution of residential prices. However, two distinct pricing characteristics appear to have been conflated, viz. (1) sharply rising prices, and (2) price discrimination and the associated dispersion of prices (see also Littlechild, 2017). The difficulty for policymakers is that misdiagnosing price discrimination for policy treatment will inflame rising prices.

When shifting from a regulated uniform monopoly price to a competitive market, the practice of price discrimination produces a wide array of prices and products. To the non-economist, the term "price discrimination" can conjure negative sentiment. Ofgem and Thwaites Reviews considered the practice produces unfair prices, creates confusion amongst consumers, and presents the opportunity for large incumbent retailers to exercise market power and price-gouge inactive customers (Ofgem, 2008, 2011; Thwaites et al. 2017). But price discrimination is unremarkable in economics, is a predictable outcome of rising competition and is frequently welfare enhancing ${ }^{6}$. Price discrimination is pervasive throughout the economy and forms a vital means by which non-trivial joint fixed and sunk costs are efficiently recovered by firms, especially in capital-intensive or "heavy" industries (see Dana, 1998; Levine, 2002; Elegido, 2011; Littlechild, 2017).

Nonetheless, perceptions of fairness inevitably arise when a menu of tariffs emerge and deviate from an historic uniform price (Dana, 1998). Deeply discounted tariffs are of course very popular. In contrast, Standing Offer tariffs in a rising cost environment are, understandably, derided by consumer groups. This in turn produces adverse media and political "focusing events". The intuitive policy response to these focus events is to stamp out the practice and limit Standing Offer tariffs to some lower level perceived to be fair. Indeed, Prime Ministers of Britain and of Australia ${ }^{7}$ weighed-in on retail energy markets in 2017 with ill-advised policy thought-bubbles of shifting all customers en-masse to the cheapest tariff (He \& Rainer, 2017; Littlechild, 2017). Implementation of such a policy would surely see cheap tariffs disappear overnight, with serious welfare implications for low income customers who, by necessity, shop around for deep discounts.

At this juncture, Official Advice given to policymakers on the welfare implications of intuitive interventions is critical because an intuitive policy response will almost certainly do more harm than good. A long line of independent academic economists in Great Britain attempted to provide advice to British regulator Ofgem (see for example Vickers, 2009; Yarrow, 2009; Hviid \& Waddams Price, 2012; Green, 2012) but were ignored and the consequences for British consumers were disastrous (Littlechild, 2014, 2017; Pollitt \& Haney, 2014; Waddams Price \& Zhu, 2016; He \& Rainer, 2017).

The purpose of this article is to analyse retail market deregulation and in particular, whether Queensland's 2016 policy initiative to deregulate prices represents a welfare enhancing policy. Queensland represents a fascinating and globally unique case study because of its common input costs and dual retail zones representing the market extremes, Southeast Queensland is fully contestable and deregulated competitive market with 1.3 million customers, while Regional Queensland comprises a control group comprising 640,000 customers in a regulated monopoly supplier setting with a uniform tariff.

Evidence presented in this article on the performance of the Southeast Queensland market supports the policy of deregulation. Distributional effects are ambiguous, however. There must be episodes of inter-consumer misallocations, albeit trivial at this stage. But Southeast Queensland has certain advantages over its British and Victorian peers; (1) Southeast Queensland has benefited from Victorian and British experience; (2) in Southeast Queensland a credible reference rate exists (i.e. set for Regional Queensland); (3) rather than vacating the field when the market was deregulated, the Queensland Department of Energy retained its

\footnotetext{
${ }^{6}$ The issue here is that setting uniform prices to average cost is known to produce deadweight losses whereas to the extent that price discrimination produces marginal prices below average cost and close to, or at, marginal cost then the resulting welfare outcomes can be expected to be improved. See Simshauser \& Whish-Wilson (2017).

${ }^{7} \mathrm{See}$ http://www.smh.com.au/federal-politics/political-news/feel-the-power-malcolm-turnbull-summons-electricity-retailers-tocanberra-for-summit-20170803-gxotv1.html
} 
consumer market resourcing and remained highly engaged, including extensive jawboning of incumbent retailers in periods leading up to annual tariff changes; which (4) provided Queensland policymakers with the requisite evidence to deal with focus event-driven media.

This article is structured as follows. Section 2 presents a review of literature. Section 3 analyses the Southeast Queensland market while Section 4 presents an analysis of the gains arising from competition and associated discriminatory practices. Section 5 reviews modes of failure. Conclusions follow.

\section{Review of literature}

While the principles of price discrimination are generally attributed to Dupuit (1844) as a means by which to fund substantial sunk costs, the formal economic theory of price discrimination dates back to Pigou (1920), who defined first-, second- and third-degree ${ }^{8}$ price discrimination. Robinson (1933) would describe strong consumer segments (i.e. low elasticity, higher price) and weak consumer segments (i.e. high elasticity, lower prices) while Stigler (1987) produced the economists' preferred and generalised definition of the practice; viz. selling goods at different price-ratios to their underlying marginal costs.

In simple terms, third-degree price discrimination involves raising prices in strong consumer segments, and lowering prices in weak consumer segments. For price discrimination to persist, consumers must not be able to unravel the variations in price (i.e. arbitrage is not possible), consumer segments must have an appreciable difference in their willingness-to-pay (i.e. strong and weak segments exist) and firms must have the ability to separate customer segments cleanly through accessing better customer information, acquiring new tariff instruments or marketing a menu of pricing structures (Pigou, 1920; Robinson, 1933; Armstrong, 2006b; Stole, 2007).

As one reviewer noted, in energy markets all consumers have the same opportunities to take advantage of lower prices but self-select into "active" or remain "rusted-on" after the retailer has published their offers. In this sense the usual conditions necessary for profitable price discrimination arise through setting a menu of tariffs without the need to know individual customer characteristics. But this same set of conditions also leads to a high risk of an interconsumer misallocation problem (i.e. the misallocation of weak consumer segments into an inelastic price). Considerable economics literature exists which analyses welfare implications of second-degree price discrimination in regulated electricity markets dating back to Clark (2011), Lewis (1941) and Coase (1946). Hausman \& Neufeld (1989) and Simshauser (2016) provide summaries of historical developments. However, third-degree price discrimination in residential electricity markets is a relatively new phenomenon with contestable retail electricity markets originating in Great Britain in 1999. Consequently, analysis of thirddegree practices in electricity markets ${ }^{9}$ only came to prominence from 2009- onwards due to developments in the British and later, Victorian electricity markets ${ }^{10}$.

\subsection{Price discrimination and perceptions of fairness}

Second-degree price discrimination is rarely considered contentious because volume discounts are intuitively logical. But third-degree price discrimination is often viewed with negative sentiment by non-economists due to perceptions of fairness (Elegido, 2011;

\footnotetext{
${ }^{8}$ As Pigou (1920) notes, price discrimination comes in three forms (viz. first-, second- and third-degree) but the focus of this article is third-degree price discrimination. With first-degree price discrimination, a monopolist sells to each customer at uniquely different prices at their absolute willingness-to-pay. Second-degree price discrimination occurs when prices vary with the quantity purchased. Third-degree price discrimination arises through intense market segmentation based on variations in consumer willingness-to-pay. See also Armstrong (2008) for further extensions.

${ }^{9}$ As one reviewer noted, in energy markets all consumers have the same opportunities to take advantage of lower prices but selfselect into "active" or "rusted-on" categories after the retailer has published their offers. In this sense the usual conditions necessary for profitable price discrimination arise through setting a menu of tariffs without the need to know individual customer characteristics.

${ }^{10}$ See for example Littlechild (2009, 2014, 2016, 2017), Davies et al. (2009), Hviid \& Waddams Price (2012, 2014), Waddams Price \& Zhu (2013, 2015, 2016), , Pollitt \& Haney (2014), He \& Rainer (2017), Simshauser \& Whish-Wilson (2017) and Nelson et al. (2018), Flores \& Waddams Price (2018).
} 
Marcoux, 2006; Simshauser \& Whish-Wilson, 2017). Bunzl's ${ }^{11}$ (2010, p.9) definition and procedural concept of fairness specifically considered the electricity tariff case, based on the late-Harvard Professor John Rawls' idealised theory of fairness and his famous phrase 'from behind the veil of ignorance', viz. public policy on energy pricing should be set not knowing whether you are rich or poor, renter or owner etc. Felder (2010) explains fairness for residential electricity markets translates to a problem of selecting the default rate that consumers are assigned, which is rarely correlated with consumption (Simshauser \& Downer, 2016).

To be sure, the practice of third-degree price discrimination is in stark contrast to the economist's model of perfect competition where a single uniform price is efficiently set to marginal cost. However, conditions required to achieve perfectly competitive markets are as common as perfect regulation (Varian, 1996; Joskow, 2010). A long list of explicit and implicit assumptions underpin perfect competition, viz. constant returns to scale, no fixed, common or sunk costs, zero transaction costs, perfect information and perfectly elastic demand. When these assumptions are progressively relaxed the stable uniform price equilibrium breaks down.

Crucially, price discrimination is not unambiguously harmful to economic welfare - on the contrary - price discrimination in capital-intensive industries is frequently welfare enhancing (Schwartz, 1986; Varian, 1996, Dana, 1999b; Levine, 2002; Baumol \& Swanson, 2003; Esteves, 2009; Elegido, 2011; Littlechild, 2014; Simshauser \& Whish-Wilson, 2017). In asymmetric markets with non-trivial fixed and sunk costs, banning the practice will usually dampen competition, facilitate collusive behaviour, harm price-sensitive consumers and leave customers overall no better-off (Vickers, 2009; Hviid \& Waddams Price, 2012; Littlechild, 2016; Waddams Price and Zhu, 2016).

Ultimately, sunk costs need to be recovered in some way and average cost pricing of electricity is known to be inefficient and if pursued will produce deadweight losses by comparison to alternate methods (Hotelling, 1938; Lewis, 1941; Coase, 1946; Boiteux, 1949; Bonbright, 1961; Nelson, 1964; Turvey, 1968; Joskow, 1976). Consequently whether from an economics or public policy perspective, price discrimination whereby non-trivial fixed and sunk costs are differentially recovered from strong (less-price sensitive) customer segments while allowing for marginal cost pricing in weak (more-price sensitive) segments is known to distribute the firm's cost-recovery task more fairly and in this sense generally displays positive distributional efficiency effects because the former are usually high-income households (Varian, 1996; Dana, 1999a; Marcoux, 2006; Elegido, 2011; Simshauser \& Whish-Wilson, 2017; Nelson et al 2018). ${ }^{12}$

\subsection{Key variables}

Key to distinguishing whether price discrimination is welfare enhancing is to identify changes in aggregate market output, i.e. expansion of total output is a necessary condition for price discrimination to be welfare enhancing ${ }^{13}$ (Schmalensee, 1981; Varian, 1985; Schwartz, 1990). Total output will expand if output contraction in the strong (i.e. non-discounted) segment is at least offset by output expansions ${ }^{14}$ in the weak segment, with the clearest case of welfare enhancing discriminatory pricing being where new markets are supplied that would otherwise not be served under uniform prices (Varian, 1996).

Corts (1998) demonstrated in an asymmetric oligopoly discriminatory prices can fall below the uniform price when ornate tariff structures are used by firms to attack rivals and steal

\footnotetext{
${ }^{11}$ Martin Bunzl is a Professor of Philosophy at Rutgers University. Brown, Faruqui \& Grausz (2015) note that Rawls was widely regarded as the most significant philosopher of the twentieth century.

${ }^{12}$ However, as one Reviewer noted energy consumption is positively correlated with incomes and the two-part tariff (i.e. the fixed charge) is likely to be distributionally regressive for low income, low consuming households.

${ }^{13}$ To be sure, it is not a sufficient condition because other industry variables (e.g. excessive switching costs or excess entry in competitive markets) can overrun welfare gains generated by expanded output.

${ }^{14}$ Noting that the energy industry is complicated by $\mathrm{CO} 2$ emissions and so for this condition to hold environmental costs need to be reflected in prices.
} 
market share, which in turn can produce 'all out competition' - an outcome not possible with monopoly ${ }^{15}$. Fundamental to understanding Corts (1998) is that profit and welfare outcomes are sensitive to whether rivals agree on strong and weak segments. When they do, firms follow a best-response symmetry in pricing decisions, and prices fall below uniform prices in weak segments, and rise above uniform prices in strong segments with ambiguous welfare impacts - yielding results consistent with Katz (1984), Borenstein (1985), Thisse \& Vives (1988), Holmes (1989), Winter (1997) and others. However, when firms disagree on strong and weak segments, they display best-response asymmetry with competition intensifying. Under such conditions, price discrimination gives firms more weapons with which to 'wage their war' (Corts, 1998, p.321). Consequently, and unlike monopoly, in imperfectly competitive markets the impact of price discrimination on both welfare and profit is ambiguous. The number of relevant variables also expands considerably. Of central importance is the symmetry of market information amongst rival firms.

Essential to understanding the present policy problem is the corollary to the Corts (1998) analysis. If asymmetric markets are forced back to uniform pricing due to policymaker intervention, rival firms will lose the weapons used to wages their war and naturally retreat to strong market segments to maximise profit (Waddams Price \& Zhu, 2016; Littlechild, 2016). Under asymmetric conditions with less competitive pressure, subsequent pricing behaviour of the firms will resemble monopoly.

Studies of price discrimination relevant to Full Retail Contestability spans the range of markets and structures. To summarise the results ${ }^{16}$ and as Stole (2007) explains, competition is usually effective at controlling average prices but is not always effective at generating the correct pattern of relative prices and represents a key source of ambiguity in the welfare analysis.

Relevant to retail electricity markets from a theoretical perspective are observations from Armstrong (2006b), viz. when entry is relatively frictionless, price discrimination will produce a higher number of firms initially. The welfare implications of excess entry are adverse (i.e. excessive industry fixed costs). But proliferation of ornate tariff structures will drive inefficient firms out over time (Armstrong, 2008).

Also of importance to retail electricity markets is empirical analysis of aviation markets by Borenstein \& Rose (1994) and Dana (1998, 1999b) who examine nuances between monopoly and monopolistic competition, and show reliance on monopoly theories will misguide policymaking. Perhaps counterintuitively, along with Stole (2007) they show price dispersion increases as competition intensifies (Klein, 1993; Borenstein \& Rose, 1994; Dana, 1999b; Levine, 2002; Baumol \& Swanson, 2003; Stole 2007). ${ }^{17}$

Electricity markets are characterised by customer poaching, franchise areas, customer loyalty, mixed product bundles (i.e electricity and gas), national vs. single region retailers, and behavioural-based poaching. Various studies have analysed analogous scenarios and again to

\footnotetext{
${ }^{15}$ In monopoly settings, firm profits can only increase with price discrimination because the firm is solving the profit maximisation problem with one less constraint, and would only chose this strategy if it were profitable (Armstrong, 2006b). Under such conditions prices disperse either side of average cost and consequently welfare impacts are ambiguous (Stole, 2007, Armstrong, 2008). In a symmetric oligopoly where firms agree on strong and weak segments, price dispersion is similar to monopoly, viz. strong and weak segment prices lie either side of the uniform price, with some consumers worse-off, and others better-off $c f$. uniform prices (Holmes, 1989). Whether total welfare is enhanced depends critically on expansion in output. ${ }^{16}$ The range of markets and structured and associated modelling results are characterised by 1) number of rivals, 2) information availability, 3) size of customer segments, 4) ease of entry, 5) size of discounts, 6) customer poaching, 7) branding and loyalty, and 8) mixed product bundles (see Katz, 1984; Borenstien 1985, Holmes, 1989; Chen, 1997; Corts 1998; Dana, 1999a; Shaffer \& Zhang, 2000, Taylor, 2003; Dobson \& Waterson, 2005, Armstrong 2006a; Stole, 2007; Armstrong, 2008; Esteves, 2009 amongst others). Additionally, in oligopolistic markets price discrimination can produce inefficient industry costs from 'excess entry', too many firms operating at sub-optimal scale, excessive customer switching and sub-optimal coordination of prices. All of these variables impact welfare analysis.

${ }^{17}$ Borenstein \& Rose (1994) also identify customer loyalty programs and advanced information systems increase price dispersion through higher prices in strong segments. Conversely, they find when markets are dominated by weak segment consumers, price dispersion contracts.
} 
summarise results ${ }^{18}$, the fact that firms can be worse-off with price discrimination in imperfectly competitive markets is a fundamental difference with monopoly theory. Monopolists are always better-off when they price-discriminate. Competitor firms are better off holding the behaviour of rivals constant. But once this assumption is relaxed, if segment information is asymmetric they are likely to be worse-off. A regulatory ban of price discrimination can facilitate tacit collusion but the key is whether firms agree on strong and weak market segments.

Market power is often assumed to be a precondition for price discrimination. This is not correct in theory or practice; indeed one strand of the price discrimination literature focuses on intensely competitive markets (Klein, 1992; Levine, 2002; Baumol \& Swanson 2003). Because fixed and sunk costs are pervasive, price discrimination is prevalent in highly competitive markets as well and occurs as the means to recover such costs in markets where no apparent market power exists (Levine, 2002; Littlechild, 2017). Dana (1998) examines certain US airline routes in the context of a market characterised by peak demand uncertainty, non-storability, underutilised capacity and intensely competitive routes (i.e. absence of market power). Dana (1999a) shows it is efficient for airlines to allocate different seats at different times and at different prices, and is not sufficient evidence that market power exists.

Indeed, in any industry with periodic demand such as airlines and the energy industry, with flat-rate tariffs the value of peak energy is under-priced while the value of off-peak energy is overpriced, and the absence of widespread time-differentiated pricing has been persistently identified as a problem facing the efficiency of electricity systems by energy economists dating at least as far back as Boituex (1949), Dessus (1949), Houthakker (1951), Steiner (1957), Nelson (1964), Turvey (1964), Joskow (1976), Crew \& Kleindorfer (1976), Wenders (1976) and Faruqui \& Malko (1983). More recent studies including Borenstein \& Holland (2005), Faruqui (2010a, 2010b), Faruqui \& Sergici (2010, 2013), Faruqui, Sergici \& Sharif (2010), Wood \& Faruqui (2010), Simshauser \& Downer (2012, 2016), Borenstein (2013), Procter (2013), Nelson \& Orton (2013), Energex \& Ergon (2014), Fenwick et al. (2014) and others have all demonstrated that time-differentiated tariff structures are capable of correcting market inefficiencies and inequities.

Levine (2002) and Baumol \& Swanson (2003) explain price discrimination is frequently how competitive firms recover costs in a way that mirrors Ramsey ${ }^{19}$ pricing, but instead of facing a regulated revenue constraint the broader market imposes a proximate revenue constraint on firms. Above all, as Varian (1996) explains, price discrimination is a means by which to increase quantities sold, not to withhold capacity - which is the necessary condition for the exercise of market power.

\subsection{Price discrimination in residential electricity markets}

In Great Britain and Victoria, regulatory authorities and policymakers have reacted adversely to price discrimination amongst the residential segment, noting discriminatory prices could not be explained by estimates of variations in cost (Ofgem, 2008, 2011; Ben-David, 2013, 2015; ACCC, 2017; Thwaites et al 2017).

In the British case, Ofgem $(2008,2011)$ observed the "Big 6" incumbent retailers offering deep discounts in rival service areas while maintaining higher Standing Offer tariffs in their own former franchise area. This describes the conventional two-period customer poaching model under best-response asymmetry (Armstrong, 2006a). As Hviid \& Waddams Price

\footnotetext{
${ }^{18}$ Bester \& Petrakis (1996) examine customer poaching; Shaffer \& Zhang (2000) extend the analysis to include franchise areas and customer loyalty; Matutes \& Regibeau (1992) and Whinston (1990) examine mixed product bundles; Dobson \& Waterson (2005) examine national retailers committing to uniform prices; Chen (1997) examines behavioural-based customer poaching; Taylor (2003) examines time and effort in a limited commitment model; Chen (2006) analyses limit pricing and Vickers (2005) examines banning discrimination as entry protection.

${ }^{19}$ Ramsey pricing was designed to be deployed in regulated monopoly industries as a means by which to recover common fixed and sunk costs in a least distortionary way, i.e. setting a high price in the relevant strong market and low price in weak markets essentially combining an inverse-elasticity rule with multi-part tariffs to recover infra-marginal costs for a given regulated revenue constraint. Ramsey pricing has long been regarded as a benign form of discriminatory pricing and preferable to uniform prices in declining cost monopoly industries. See Ramsey (1927).
} 
(2012) and Littlechild (2014) explain, Ofgem set out to eliminate discriminatory prices by regulatory policy on the basis that differentials were unfair and reflected the exercise of market power. But the regulator had misinterpreted the market; as Borenstein \& Rose (1994), Dana (1998, 1999a, 1999b), Armstrong (2006b), Stole (2007) and others explain, rising price dispersion can be expected as competition intensifies, not the other way around. And as Klein (1993) and Levine (2002) warn, price discrimination should not be misdiagnosed as a sideeffect of market power. New products and tariffs are how firms attract and 'poach' a rival's idle customer segments and is not evidence of market power or market failure (Baumol \& Swanson, 2003; Littlechild, 2014).

The regulatory policy imposed by Ofgem was a retail licence condition of common mark-ups across regions to halt discriminatory mixed bundling and behavioural-based customer poaching in an asymmetric Corts (1998) market. Drawing from Katz (1984), Thisse \& Vives (1988) and Corts (1998), theory predicts that firms will retreat to strong markets when discriminatory practices are banned. And as Hviid \& Waddams Price (2012), Pollitt \& Haney (2014), Littlechild (2014) and Waddams Price \& Zhu (2016) explain, British energy retailers did retreat to their strong markets, removed competitive tariffs, competition declined, discounts contracted, switching rates fell as gains from switching diminished, customer poaching slowed, overall tariff mark-ups began to rise and energy retailer profits increased materially (up $£ 1$ billion pa).

In Australia, a steady line of inquiry on discriminatory prices has emerged in Victoria (BenDavid 2013, 2015; Dufty \& Johnson, 2014; CME, 2015; Grattan, 2017) culminating in the Thwaites and ACCC Reviews. The Thwaites Review argued households were paying $21 \%$ higher than official estimates and average bills were $\$ 500$ more than the lowest Market Offer (albeit based on a sample of 682 consumer accounts). The Review found retailer charges had risen sharply, and Australia's "Big 3 Gentailers" dominated the market with their significant low-cost advantage but failed to translate these into lower prices. The market was judged to be confusing; discounts were not pegged to a common reference rate and two-part tariffs (i.e. fixed charge and variable rate) meant some discounts only applied to the variable rate. ${ }^{20}$

Analysing the same market, Simshauser \& Whish-Wilson (2017) contrasted the fully deregulated Victorian market with the (then) semi-deregulated Southeast Queensland market which retained a regulated price cap. Price dispersion was more pronounced in Victoria; the marginal Market Offer had zero profit margin ( $c f$ semi-deregulated Southeast Queensland with 6.7\% profit mark-ups) while Standing Offers were $10 \%$ above average cost. Littlechild (2017, p.8) explains how this occurs:

In some circumstances, firms have no choice: the pressure of competition can force them to discriminate, simply to survive (Baumol, 2006). The retail energy market appears to be such a case. Retail suppliers are driven by competition to reduce prices to the most active customers (to try and keep those customers most prepared to leave, and to try to attract replacement customers from other suppliers). These prices are driven down towards operating cost. So suppliers have to try and recover their overhead costs from their less active customers. But all their tariffs are subject to competition because all customers can switch.

Importantly, a majority of Victorian households were better-off than a counterfactual regulated uniform price even though Standing Offers were 10\% above average cost. Only $11 \%$ of households had not shifted to Market Contracts. However, analysis of a Big 3 retailer's private data found $4.9 \%$ of customers were on a Standing Offer (strong segment)

\footnotetext{
${ }^{20}$ The Review further found consumers needed to remain engaged and switch regularly to ensure they remained on competitive tariffs and consumers experience a significant loss of benefit whenever they cannot identify the single best offer in the market. Status quo bias was argued to create a sticky consumer problem. The Review concluded "these elements point to the fact that the market is failing consumers" and that strong intervention is required, including a regulated Basic Service Offer product with an unconditional obligation to supply (Thwaites et al, 2017 p.x). Other recommendations included a change from un-anchored percent discount to absolute dollars savings with the independent regulator to develop 3-4 standard customer reference points, and a requirement to roll contracted customers onto the nearest matching offer at the end of any contract period to avoid an automated reversion to Standing Offer tariffs.
} 
and were vulnerable (weak segment) and had thus been misallocated by the market (i.e. interconsumer misallocation). Consistent with Stole (2007), the Victorian market had been successful at regulating the average price but had not generated the correct pattern of relative prices for about 100,000 vulnerable households (out of 2.4 million households).

In an earlier study Simshauser \& Downer (2016) found Victorian households in hardship consumed 33\% more than the average household. Nelson et al. (2018) extended the analysis contained in Simshauser \& Whish-Wilson (2017) by focusing on non-vulnerable Standing Offer customers in Victoria, and found they consumed 18\% less than households on discounted products. This has important implications in that the inactivity of many Standing Offer customers may be consistent with Littlechild's (2016b) thesis; that such inactive customers exist does not represent a market failure - from a practical perspective they spend $1.6 \%$ of household income on electricity ${ }^{21}$ and simply put, their time is better spent elsewhere. This is consistent with the basic premise of perceived gains driving switching activity (see IPART, 2013; Simshauser, 2014; Littlechild, 2014; He \& Rainer, 2017; Flores \& Waddams Price, 2018). That is, households may maximise welfare by remaining disengaged and on a higher-priced Standing Offer.

\section{Analysis of the Southeast Queensland Retail Electricity Market}

The Queensland market makes for a fascinating case study because unlike other jurisdictions, it comprises common input costs with two retail zones, a fully deregulated zone and a regulated monopoly supply zone:

- Southeast Queensland (1.3 million customers) is a fully contestable, highly competitive and deregulated retail electricity market with a single network service area, two incumbent retailers and 18 new entrants; and

- Regional Queensland (640,000 customers) has a monopoly distributor-retailer with a regulated uniform tariff based on the Southeast Queensland economic cost of supply as its Benchmark tariff.

These circumstances enable direct comparison of two residential electricity retail market extremes with Regional Queensland effectively comprising a 640,000 customer control group. Figure 1 provides a map of Queensland and highlights the deregulated Southeast "Energex" distribution service area and the monopoly Regional "Ergon" distribution service area.

\footnotetext{
${ }^{21}$ Household expenditure data from the Australian Bureau of Statistics reveals that the average households spend $2 \%$ of income on electricity. $18 \%$ less implies $1.6 \%$.
} 


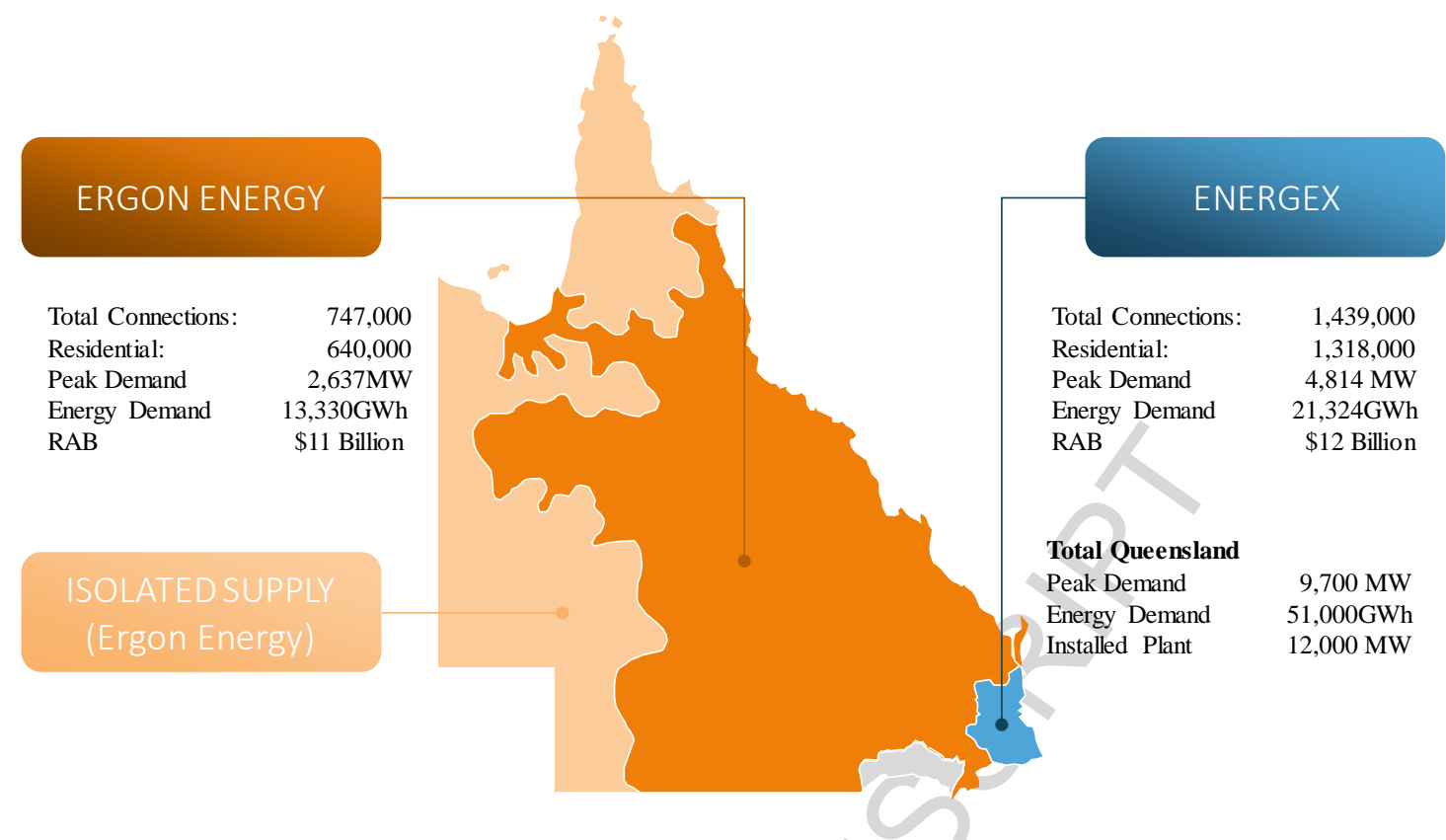

Note that because Queensland is a single wholesale region of the NEM, wholesale and retail costs are identical. To be clear, the underlying Transmission and Distribution network charges (and losses) are materially higher in Regional Queensland but the method of charging is based on the actual costs in the Southeast due to a long-standing Uniform Tariff Policy (i.e. Regional Queensland customers pay the same network tariff as Southeast Queensland customers with losses funded by a State Government subsidy ${ }^{22}$ ).

Queensland implemented a policy of Full Retail Contestability policy for the (non-subsidised) Southeast Corner in 2007 and a regulated price-cap was retained as a transitional measure. The Australian Energy Market Commission examined Southeast Queensland in 2014 and concluded it was "workably competitive" and that transitional price-caps were no longer necessary. On the contrary, there had been episodes of erroneous regulatory price-cap decisions that damaged retail market performance (see Section 3.4). In 2014 the (then) conservative state government announced it would deregulate Southeast Queensland from 2015. A general election produced a change of government, but the new Labor Cabinet nonetheless committed to deregulation, albeit after a one year delay in 2016.

Less than 12 months after deregulation in Southeast Queensland, a politically-motivated inquiry into Australian retail electricity markets was launched by the Commonwealth Government. The "Retail Electricity Pricing Inquiry" was undertaken by Australia's antitrust commission, the ACCC (2017, pp.99-100) which along with other regions took-aim at Southeast Queensland retailers:

“...inactive customers who stay on a Standing Offer [in Southeast Queensland] may be paying up to $\$ 517$ more than the regulated rate, and more than $\$ 700$ more than the cheapest market offer. These are substantial differences in price outcomes for what is a largely homogeneous service..."

\footnotetext{
${ }^{22}$ By way of brief background, Regional Queensland is a regulated monopoly supply service area due to Queensland's longstanding Uniform Tariff Policy. This bipartisan political policy has been in existence since the early-1970s and serves to ensure Regional Queensland residential consumers pay no more for electricity than their Southeast Queensland city counterparts. As Figure 1 notes, Energex (Southeast Queensland) has a Regulatory Asset Base of \$12bn and serves 1,318,000 residential connections, while Ergon (Regional Queensland) has an \$11bn Regulatory Asset Base with only 640,000 residential connections. Network charges in Ergon's service area are therefore materially higher. The cost of the Uniform Tariff Policy is typically $\$ 300-\$ 500 \mathrm{~m}$ per annum and is funded by a State Government subsidy to the (state-owned) monopoly distributorretailer, Ergon Energy.
} 
Such a quote ${ }^{23}$ could be expected, and did, make headlines in State-wide newspapers. ${ }^{24}$

In order to assess the competitive state of Southeast Queensland retail electricity market, seven lines of quantitative inquiry are presented and analysed, including (1) the level of tariffs; (2) the structure of tariffs including a comparison between Regulated, Standing and Discounted Market Offer tariffs; (3) customer switching rates across industries, NEM regions and Southeast Queensland; (4) the number of rival retailers; (5) the number of inactive or "rusted-on" customers; (6) the level of price dispersion, and (7) a comparison of Standing and Market Offers.

\subsection{Defining the problem: price discrimination or price rises?}

Why is the residential electricity sector singled out for special attention when price discrimination is pervasive throughout the economy? The business segment of electricity markets exhibits extensive second- and third-degree practices, yet is never questioned by policymakers. In my professional opinion, there are three reasons:

1. Household (i.e. voter) access to electricity is a basic human right (Tully, 2006);

2. Residential electricity supply has a $100+$ year history of uniform tariffs;

3. Soon after deregulation the underlying cost of electricity increased sharply in Great Britain (Littlechild, 2017) and the NEM (Simshauser, 2014).

In the British experience, energy cost increases were driven by international energy prices (i.e oil and gas) and environmental costs which led to marked Year-on-Year changes from 2005 (Littlechild, 2016, 2017). Policymakers and regulators had a distinct change in attitude towards the performance of the deregulated British retail market from 2008 (see Waddams Price \& Zhu, 2016; Littlechild, 2016; He \& Rainer, 2017). Australia's electricity price rises were not synchronised with Great Britain. They became marked four years later from 2009 as Figure 2 reveals. The lead-time for the change in attitude towards retail market performance was synchronised - about 3-4 years after non-trivial price increases (see Ben-David, 2013; Dufty \& Johson, 2014; Ben-David, 2015; CME, 2015; ACCC, 2017; Thwaites et al. 2017).

To understand the evolution of non-trivial price increases in Australia, Figure 2 presents average retail tariffs for Queensland from 1955-2018 in nominal and real terms.

\footnotetext{
${ }^{23}$ In an apparent regulatory echo-chamber, the same conclusion was made of the British market by the CMA (2016, p.9) a year earlier: ... there is a wide variation in the prices that different domestic customers pay for energy, which is particularly striking since electricity and gas are entirely homogenous products... for some categories of customer, the average gains from switching were equivalent to more than $20 \%$ of their bill...

${ }^{24}$ Ironically, the ACCC $(2017$, p124) cited Australia's jurisdictional regulator with the least experience in competitive retail electricity markets in Australia, the ICRC from the Australian Capital Territory, who suggested "price dispersion may only be reflecting information asymmetry and search costs" - implying that stamping out the practice will somehow enhance welfare. Economic theory and British market experience (Section 2) is very clear about this; price dispersion rises with competitive intensity. Market offers and ornate tariff structures proliferate and are merely weapons used against rivals. Efforts to stamp-out the practice will damage consumer welfare and increase the profits of firms (Hviid \& Waddams Price, 2012; Pollitt \& Haney, 2014; Littlechild, 2016, 2017; Waddams Price and Zhu, 2016; Flores \& Waddams Price, 2018).
} 
Figure 2: $\quad$ Queensland average residential electricity tariff (1955-2018)

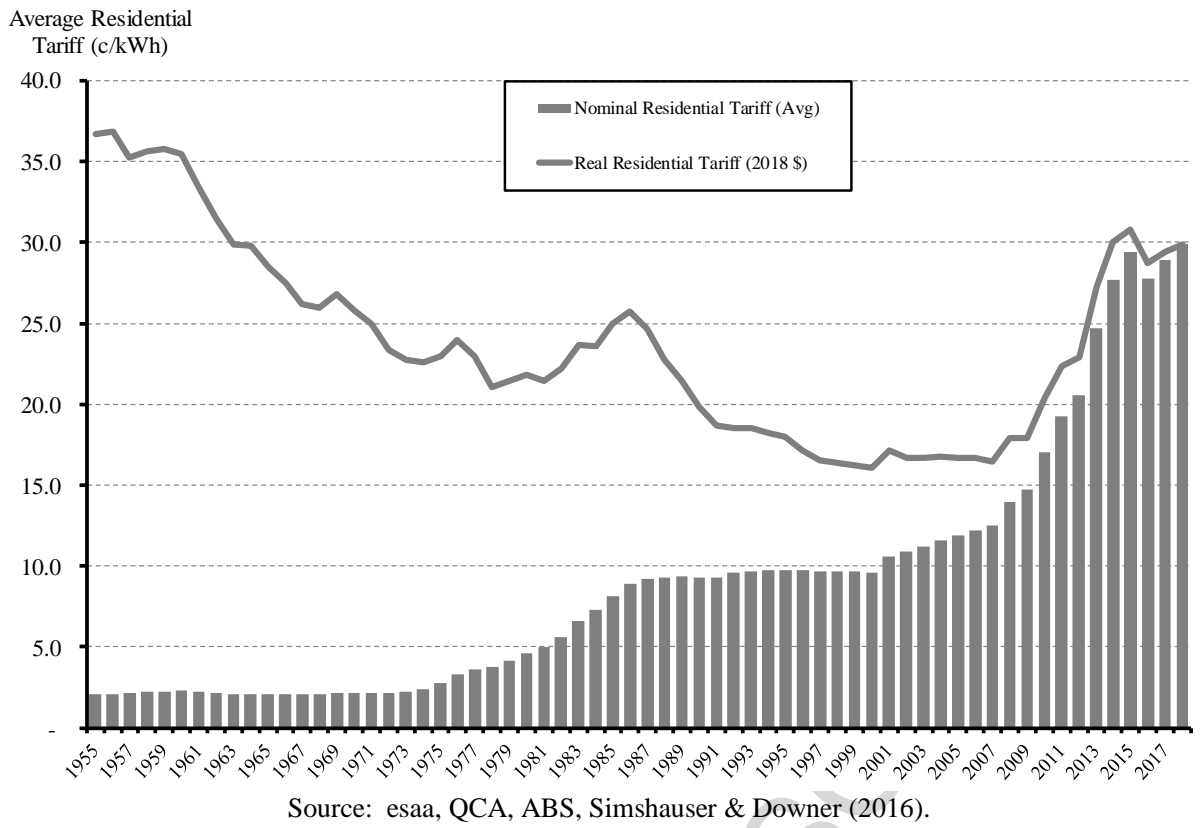

It took 45 years of technological advancement, scale economies and microeconomic reform from 1962-2007 to drive real tariffs from 30c/kWh down to $16 \mathrm{c} / \mathrm{kWh}$. Policy error would unwind those gains in seven years (2007-2014). For households, tariff increases were material and sustained. Each jurisdiction of Australia's NEM experienced some variation to the Figure 2 data but the general trend was consistent. Three distinct drivers were responsible for material tariff increases from 2007, viz. network policy failure ${ }^{25}(2007-2013)$, environmental schemes ${ }^{26}$ (2011-2017) and wholesale prices ${ }^{27}$ (2015-2018). These pricing effects were sequential and cumulative. Compounding matters, the run-up in electricity prices occurred in the post-Global Financial Crisis era of low general inflation, low wages growth and in some jurisdictions coincident record-high housing costs. Perhaps unsurprisingly, as with Great Britain, electricity prices and retail electricity markets became a cost of living focus event for politicians (see Littlechild, 2014; Waddams Price \& Zhu, 2016; Simshauser, 2016; He \& Reiner, 2017; Nelson et al. 2018; Simshauser \& Tiernan, 2018).

\subsection{Regulated Tariff vs. unregulated Standing Offers and Discount Offers}

Queensland's Uniform Tariff Policy means the State's independent economic regulator must make an annual assessment of the economic cost of electricity supply for the Southeast Queensland residential segment, and apply this regulated tariff to Regional Queensland residential customers. Consequently, unlike all other regions in the NEM, Queensland has an independent Benchmark. To be clear, the regulator's tariff setting methodology is not unanimously supported (Simshauser, 2014) but it is nonetheless transparent and consistently applied. The tariff determination for 2017/18 is presented in Figure 3 along with comparisons to deregulated Standing Offers and the best available Market Offer.

\footnotetext{
${ }^{25}$ In relation to network policy failure, in the 2004 summer Southeast Queensland experienced a series of extreme weather events which produced three severe episodes of distribution network-related load-shedding. These were a political disaster because Energex, a government-owned distribution network company, had aggressively reduced operating and capital expenditures in prior periods to raise productivity and returns (as requested by Shareholding Departments). An inquiry into the blackouts recommended a change in planning standards, from stochastic to deterministic, which produced a form of Averch \& Johnson (1962) gold-plating. The huge expansion in the capital base commenced soon after, with network tariffs more than doubling from 2007-2013 (Simshauser, 2014b).

${ }^{26}$ Four environmental schemes impacted tariffs from 2011-2017. To be clear, each scheme was trivial but combined they aggravated network-driven tariff increases. Schemes included i). solar Feed-in Tariff (Nelson et al 2012; Simshauser, 2016); 20\% Renewable Energy Target which was separated into two, viz. ii). small-scale and iii). utility scale (Jones 2009; MacGill 2010; Buckman and Diesendorf 2010; Nelson et al. 2013) and iv). the carbon tax from 2012-2014 (Freebairn, 2014 ; Wild et al. 2015). At their peak, environmental schemes added $15 \%$ to an already sharply rising tariff (Simshauser \& Downer, 2016). ${ }^{27}$ As Great Britain experienced a decade earlier, wholesale prices in the NEM doubled (in some regions, tripled) from 2015 2017. A supply-side crisis occurred following the closure of $18 \%$ of the coal-fired fleet (Simshauser \& Tiernan, 2018). Decades of climate change policy discontinuity had taken a toll on supply-side additions in prior periods, and consequently coal plant exit was not matched by adequate entry coupled with acute problems in the market for natural gas (Simshauser \& Nelson, 2015).
} 
Figure 3: $\quad$ Qld Tariff build-up, Regulated Rate vs Standing Offers and Best Market Offer

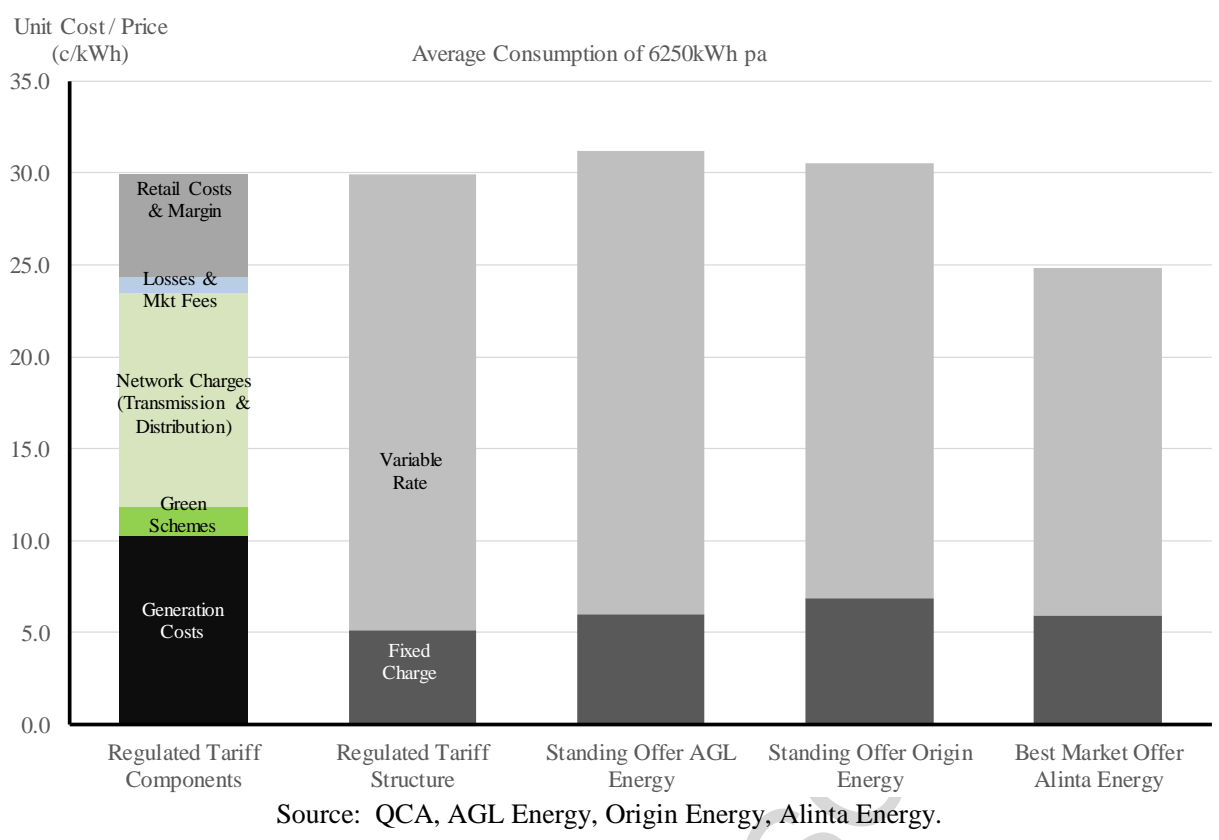

The first bar in Figure 3 illustrates the cost-components of the regulated tariff applied to the 640,000 residential customers in Regional Queensland - and to be clear - is based on the estimated economic cost of supply to a consumer in Southeast Queensland. The $2^{\text {nd }}$ bar shows the Benchmark structure, viz. a two-part tariff with the fixed charge comprising roughly $20 \%$. Apart from the general residential consumption tariff (Tariff 11), large numbers of Queensland households also access discounted (load controlled) hot water//pool pump tariffs, known as Tariffs 31 and 33. Data in Figures 2-3 represent a blended average of two tariffs in proportion to their general use. ${ }^{28}$ Next are Standing Offers of incumbent retailers, AGL Energy (352,000 customers) and Origin Energy (630,000 customers). Finally is the deepest 'routine discount' Market Offer from $2^{\text {nd }}$ Tier retailer Alinta Energy (53,600 customers).

\subsection{Customer activity - customer switching rates in Southeast Queensland}

Customer switching is frequently used as a headline measure of the health of contestable residential electricity markets. Switching rates in Southeast Queensland and NEM regions have typically averaged $16-22 \%$ per annum. This compares favourably to the British residential energy market (11-13\%) following earlier damage done by Ofgem (Littlechild, 2016; He \& Reiner, 2017). It is helpful to place Southeast Queensland customer switching rates in context by contrasting other industry rates (see Table 1).

Table 1: Industry comparison of customer switching rates

Industry Switching Rate

\begin{tabular}{ll}
\hline NEM & \\
Electricity & 21.8 \\
NEM Gas & 15.9 \\
Broadband & 15.0 \\
Mobile Phones & 13.0 \\
Pay Television & 12.0 \\
Insurance & 12.0 \\
Airlines & 10.0 \\
Banking & 8.0 \\
Health & 4.0
\end{tabular}

\footnotetext{
${ }^{28}$ In this instance, $5000 \mathrm{kWh}$ on Tariff 11 , and $1250 \mathrm{kWh}$ on Tariff 33 . Tariff 31 is an alternative to Tariff 33 - it has a lower price but a higher level of interruptability. For the purpose of the present analysis, the higher priced Tariff 33 has been used. 
Superannuation 4.0

Sources: Simshauser (2014), AEMO.

Detailed historic data for Southeast Queensland and the other primary ${ }^{29}$ NEM regions is presented in Table 2. Note the run-up in Southeast Queensland customer switching from the 2016/17 Financial Year, the first year following price deregulation.

Table 2: Customer switching by NEM Region (2007/08-2017/18 $\left.{ }^{30}\right)$

\begin{tabular}{ccccc}
\hline Fin Year & SE QLD & VIC & NSW & SA \\
\hline $2007 / 08$ & 20.3 & 22.4 & 10.2 & 18.3 \\
$2008 / 09$ & 20.7 & 25.4 & 10.9 & 15.0 \\
$2009 / 10$ & 23.3 & 25.9 & 12.8 & 13.9 \\
$2010 / 11$ & 25.3 & 27.1 & 14.0 & 18.6 \\
$2011 / 12$ & 21.2 & 26.8 & 17.3 & 22.1 \\
$2012 / 13$ & 18.1 & 28.7 & 20.1 & 22.0 \\
$2013 / 14$ & 17.0 & 27.3 & 15.2 & 18.3 \\
$2014 / 15$ & 16.7 & 26.6 & 15.9 & 16.0 \\
$2015 / 16$ & 16.8 & 24.6 & 16.9 & 16.3 \\
$2016 / 17$ & 22.1 & 27.4 & 18.6 & 16.5 \\
$2017 / 18$ & 30.4 & 29.0 & 20.7 & 19.1 \\
\hline 5Yr Avg & 20.6 & 27.0 & 17.5 & 17.3 \\
\hline Source: AEMO, AGL Energy. & & &
\end{tabular}

Figure 4 presents Year-on-Year customer switching velocity for Southeast Queensland (monthly resolution) for the seven-year period prior to price deregulation (2009-2016), and two-year period following deregulation (2016-2018), annotated with key regulatory events. Note during the regulated pricing period there are two sharp declines in Year-on-Year customer switching. In both instances, the regulated tariff cap was set at levels below market expectation with an effect of compressing price dispersion (Simshauser, 2014). In contemplating the impact on the NEM, Yarrow $(2008$, p15, p21) explains the consequence of such policy:

...price regulation in competitive market situations generally harms economic efficiency... It can be said that regulators, no matter how wise and no matter how well resourced, could be expected to make significant mistakes - because the problem has to do with information. The determination of a competitive price is a process that makes use of huge amounts of information, of such scale and scope as cannot feasibly be processed by a single decision-making unit such as a regulatory agency...

\footnotetext{
${ }^{29}$ There are two other regions of the NEM, the Australian Capital Territory (ACT) and Tasmania. Neither have truly competitive markets due to excess-regulation.

${ }^{30}$ Data for $2017 / 18$ has been annualised
} 
Figure 4:

Customer switching velocity in Southeast Queensland (2009-2017)

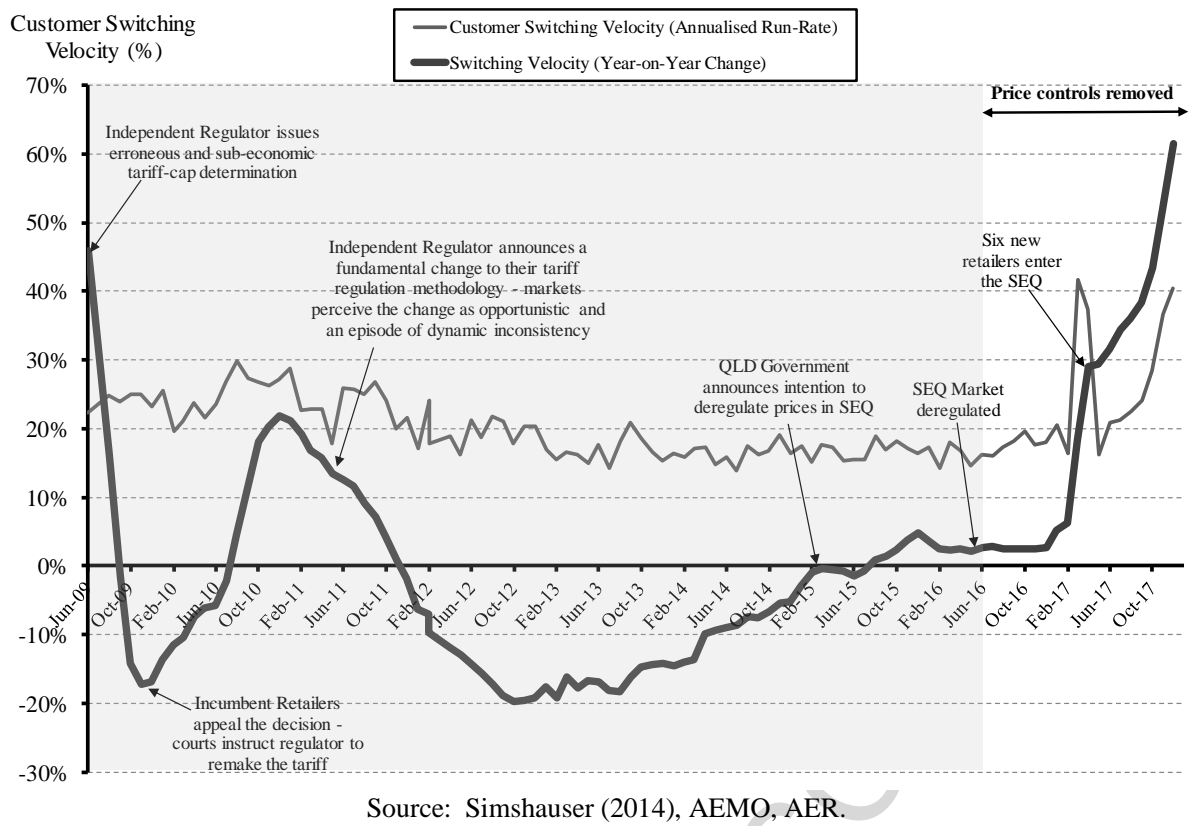

\subsection{Competitive intensity - the number of active retailers in Southeast Queensland}

Regulatory determinations and policy decisions impact the number of rivals in competitive markets, both positively and negatively, and in turn the depth of discounting, consumer gains and market activity. The first adverse regulatory determination in 2009 was relatively short lived as Figure 4 indicates - incumbent retailers appealed the erroneous determination and the tariff was swiftly reset by court order, and switching rates rebounded. However, soon after the independent regulator fundamentally altered their tariff determination methodology when the market was oversupplied. The policy methodology was seen as opportunistic, and as Kydland \& Prescot's (1977) theory on dynamic inconsistency would suggest, resulted in the exit of retailers and soon after switching rates contracted as Table 3 and Figure 4 illustrate. Conversely, the announcement of price deregulation in late-2014, and its implementation from July 2016 has seen the number of rival retailers expand from 12 to 20 .

Table 3: Retailers in the Southeast Queensland market

\begin{tabular}{cccc}
\hline Fin Yr & $\begin{array}{c}\text { Number of } \\
\text { Retailers }\end{array}$ & $\begin{array}{c}\text { Change in } \\
\text { Retailers }\end{array}$ & $\begin{array}{c}\text { YoY Chg in } \\
\text { Switching } \\
(\%)\end{array}$ \\
\hline $2007 / 08$ & 8 & 0 & 0.0 \\
$2008 / 09$ & 9 & +1 & -5.6 \\
$2009 / 10$ & 10 & +1 & 26.1 \\
$2010 / 11$ & 8 & -2 & 10.0 \\
$2011 / 12$ & 10 & +2 & -15.2 \\
$2012 / 13$ & 11 & +1 & -13.8 \\
$2013 / 14$ & 13 & +2 & -5.5 \\
$2014 / 15$ & 12 & -1 & -0.8 \\
$2015 / 16$ & 14 & +2 & 1.9 \\
$2016 / 17$ & 16 & +2 & 33.1 \\
$2017 / 18 *$ & 20 & +4 & 48.9 \\
\hline
\end{tabular}

*Annualised

Source: QCA, AER. 


\subsection{The level of "rusted-on" customers}

Another residential market metric that requires monitoring by policymakers is so-called "rusted-on" customer numbers, i.e. customers who have never switched and remain rustedon to incumbent retailer Standing Offer tariffs. Hviid \& Waddams Price (2014) explain consumers do not always respond immediately to better deals and thus one should not expect full market turnover. He \& Reiner (2017, p.27) note that according to some, rusted-on customers are evidence of market power and barriers to competition, which has disadvantaged certain groups. But they also note by contrast Littlechild's (2016b, p.635) observation that these 'sleeper customers' may be 'annoyed rather than grateful to be disturbed'. Recall from Section 2 Nelson et al. (2018) showed average consumption levels of Victorian Standing Offer customers were 18\% lower than Market Offer customers. Table 4 presents rusted-on customer results for Southeast Queensland and the other primary NEM regions:

Table 4: Year of reform and market customers vs. "rusted-on" customers

\begin{tabular}{|c|c|c|c|c|c|}
\hline Region & $\begin{array}{c}\text { Full Retail } \\
\text { Contestability } \\
\text { (Year) }\end{array}$ & $\begin{array}{c}\text { Price } \\
\text { Deregulation } \\
\text { (Year) }\end{array}$ & $\begin{array}{c}\text { Total } \\
\text { Customers }\end{array}$ & $\begin{array}{c}\text { Default } \\
\text { Customers }\end{array}$ & $\begin{array}{c}\text { "Rusted-on" } \\
\text { Customers } \\
(\%) \\
\end{array}$ \\
\hline SE QLD & 2007 & 2016 & $1,317,957$ & 226,018 & 17.0 \\
\hline NSW & 2002 & 2014 & $3,534,894$ & 813,000 & 23.0 \\
\hline SA & 2003 & 2013 & 864,876 & 121,000 & 14.0 \\
\hline VIC & 2002 & 2009 & $2,807,280$ & 281,000 & 10.0 \\
\hline
\end{tabular}

Source: AEMC, AEC, AEMO, AGL Energy, Origin Energy.

Table 4 notes Victoria is the oldest of the deregulated markets (2009) with the lowest number of rusted-on customers (10\%). After deregulating in 2016, 17\% of Southeast Queensland customers are rusted-on. These results compare favourably to the British Market, which has about 33\% of rusted-on customers after Full Retail Contestability in 1999 and price deregulation in 2002 (Littlechild, 2016; He \& Reiner, 2017).

The evolution of customers leaving the Default Tariff in Southeast Queensland and the Yearon-Year change is illustrated in Figure 5. Notice the slowing of customers leaving the Default following the regulatory changes in 2010/11, and the pickup in Market Contracts once deregulation had been telegraphed to the market from late-2014.

Figure 5: $\quad$ Share of customers now on a market contract

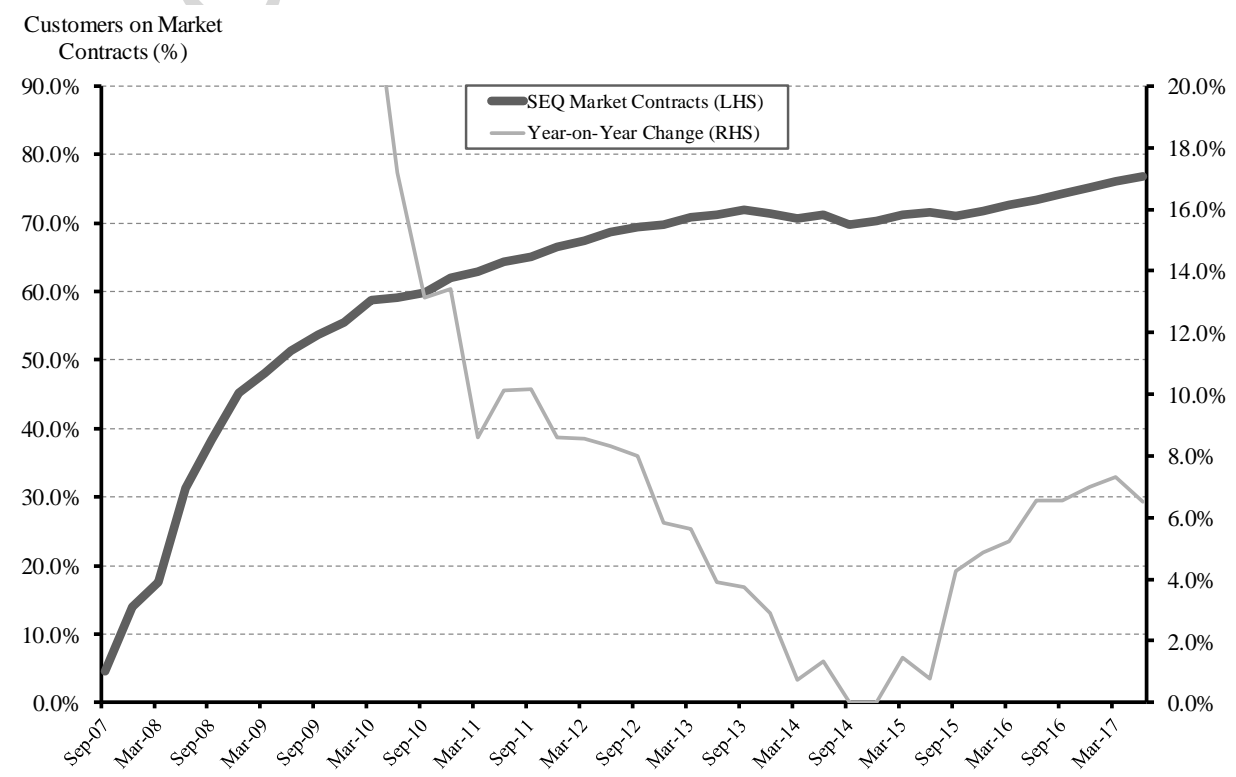


Comparing Southeast Queensland customer switching against other markets (Table 1), adjacent regions (Table 2), historical results (Figure 4), the number of active retailers (Table 3 ) and customer movements from Standing Offers (Table 4, Figure 5) does not reveal any non-price cause for alarm.

\subsection{The level of price dispersion in Southeast Queensland}

The final matter of interest is the extent of price dispersion. With the number of retailers in the market expanding from 12 to 20 following two years of deregulation, the number of Standing Offers and best routine discounts has expanded to 40 (with 128 individual products given different metering arrangements, product mixes and rival retailers, see Appendix I) and the dispersion of tariffs has increased in line with general findings in the literature. In Figure 6, "2015 Pre-Deregulation Standing \& Market Offers" have been reproduced from Simshauser \& Whish-Wilson (2017) and inflated to 2018 dollars, while 2018 data has been drawn from prevailing Standing \& routine discounted Market Offers.

Figure 6:

Tariff dispersion: pre- and post-deregulation tariffs vs Benchmark

Average Tariff Rate

(c/kWh)

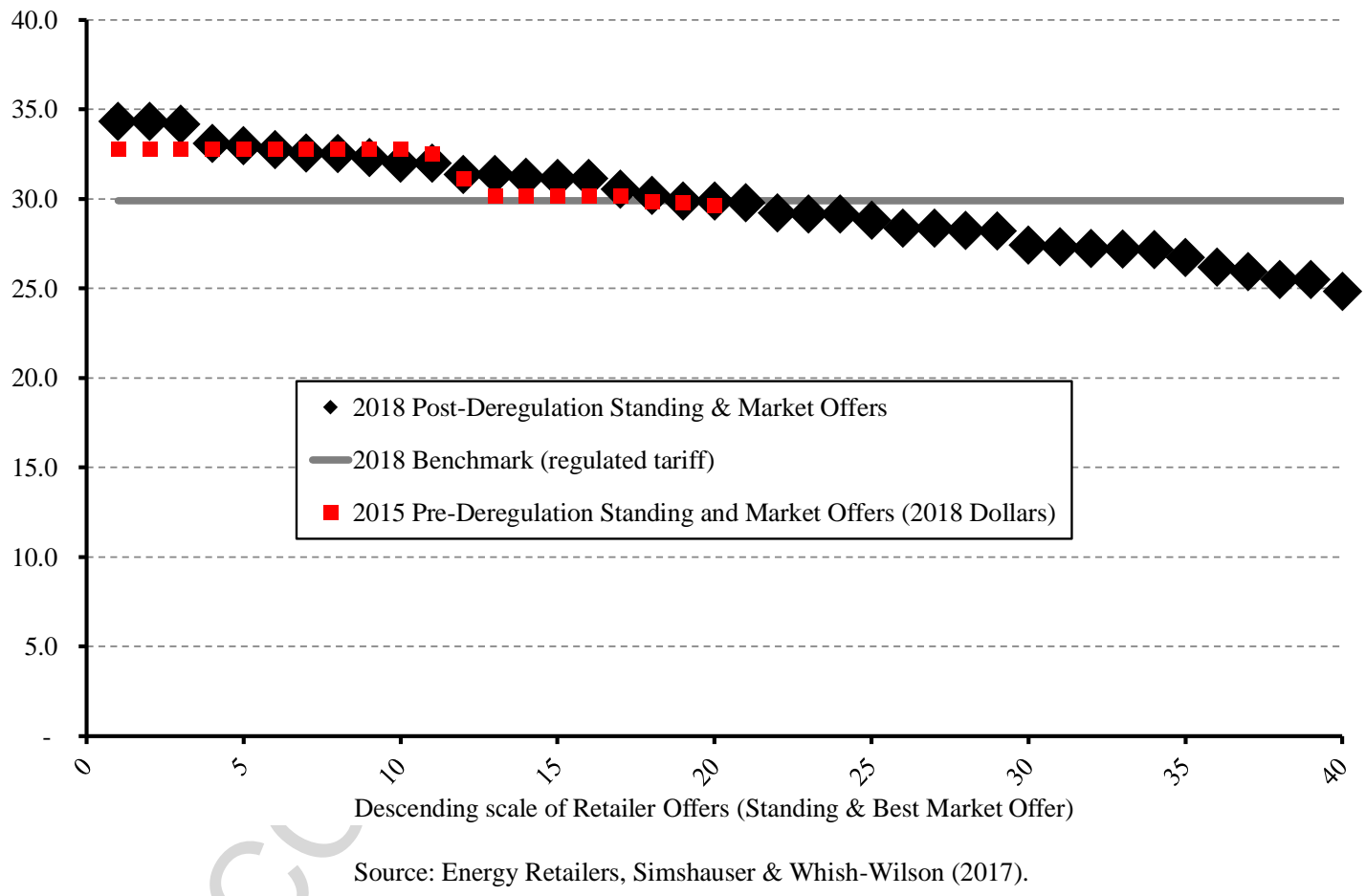

The spread of Offers either side of Benchmark is now approximately $+15 /-17 \%$. Table 5 summarises headline results from a consumer perspective. Click Energy's Standing Offer customers would theoretically pay $\$ 277$ more than Benchmark. Of course, as a $2^{\text {nd }}$ Tier retailer Click Energy has no "rusted-on" customers, and only 200 new customers yet to sign any retail offer with any retailer, and so have defaulted to Click Energy's Standing Offer tariff (such customers are known as "Occupier" or "Dear Customer" accounts ${ }^{31}$ ).

Click Energy started with a zero customer base, all customers have been poached from rivals and Click's discounted Market Offer contract is currently set to 22\% off Standing Offer rates (about $\$ 50$ below Benchmark). However, what this analysis does not capture is Click Energy's Solar PV Feed-in Tariff, viz. 16c/kWh $-60 \%$ higher than the regulatory Benchmark

\footnotetext{
${ }^{31}$ Occupier or Dear Customer accounts arise from a change of occupancy of a premises. That is, when a new home occupier arrives and the electricity remains connected, the customer defaults to the previous owner's retailer. At this point they commence on a Standing Offer until they make themselves known to the prevailing retailer. Such customers are also dominant amongst bad debts (i.e. because their full contact details remain unknown until the customer declares them.
} 
of $10 \mathrm{c} / \mathrm{kWh}$. From this we may deduce Click's strategy is focused on accumulating solar PV customers.

The lowest Standing Offer comes from PeopleEnergy, which is $5.1 \%$ below Benchmark. For the so-called rusted-on customers with incumbent retailers Origin Energy and AGL Energy, Standing Offer tariffs are 2.1\% (\$40) and 4.1\% (\$82) above Benchmark, respectively. Table 5 also presents the four most competitive "routine" discounted products. What this table does not reveal is non-routine discounts, viz. those offered prior to switching away from a retailer. These will typically come close to, or match, the prevailing market leader.

Table 5: Standing \& Market Offers vs. Regulated Benchmark for a 6250kWh consumer

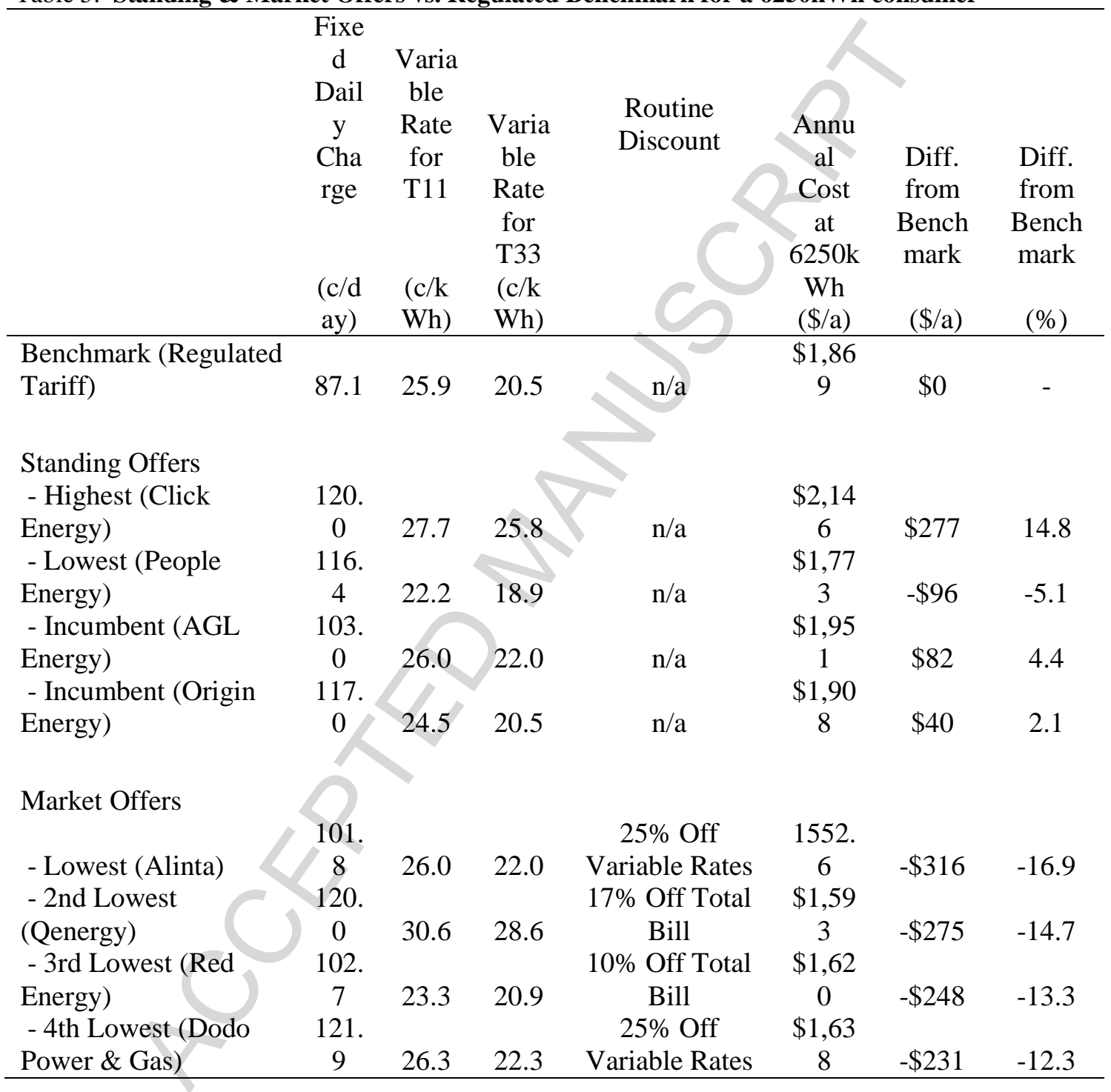

\section{Quantitative analysis of Southeast Queensland customer market data}

Australian energy retailers have historically treated their customer numbers as highly confidential. During the course of this research, Southeast Queensland retailers agreed to provide total residential account numbers and Standing Offer tariff customer numbers to the author. These data, along with Standing Offers and Routine Discounts, are presented in Table 6.

\begin{tabular}{lccccccc}
\multicolumn{6}{l}{ Table 6: } & Retailers, Customer Numbers, Standing Offer \& Routine Discount (as at Qtr2 2017/18) \\
\hline Energy & Total & Standin & Market & Fixed & T11 Variable & T33 Variable & \\
Retailer & Custom & g Offer & Custom & Rate & Rate & Rate & Routine Discounts \\
& ers & Custom & ers & & & &
\end{tabular}




\begin{tabular}{|c|c|c|c|c|c|c|c|}
\hline & & ers & & $\begin{array}{c}(\mathrm{c} / \mathrm{kWh} \\
)\end{array}$ & $(\mathrm{c} / \mathrm{kWh})$ & $(\mathrm{c} / \mathrm{kWh})$ & \\
\hline 1st Energy & $\begin{array}{c}500 \\
352,00\end{array}$ & 20 & $\begin{array}{c}480 \\
287,70\end{array}$ & 117.5 & 28.0 & 24.7 & $\begin{array}{l}18 \% \text { Off Variable } \\
\text { Rates } \\
15 \% \text { Off Variable }\end{array}$ \\
\hline AGL Energy & 0 & 64,300 & 0 & 103.0 & 26.0 & 22.0 & $\begin{array}{l}\text { Rates } \\
25 \% \text { Off Variable }\end{array}$ \\
\hline Alinta Energy & 53,616 & 161 & 53,455 & 101.8 & 26.0 & 22.0 & $\begin{array}{l}\text { Rates } \\
15 \% \text { Off Variable }\end{array}$ \\
\hline Amaysim & 0 & 0 & 0 & 120.0 & 27.7 & 25.8 & Rates \\
\hline $\begin{array}{l}\text { Click Energy } \\
\text { Diamond }\end{array}$ & 60,000 & 200 & 59,800 & 120.0 & 27.7 & 25.8 & $22 \%$ Off Total Bill \\
\hline $\begin{array}{l}\text { Energy** } \\
\text { Dodo Power }\end{array}$ & 7,500 & 200 & 7,300 & 127.6 & 26.5 & 22.5 & $\begin{array}{l}10 \% \text { Off Total Bill } \\
25 \% \text { Off Variable }\end{array}$ \\
\hline$\&$ Gas & 15,000 & 0 & 15,000 & 121.9 & 26.3 & 22.3 & Rates \\
\hline Energy & 107,68 & & 105,44 & & & & $20 \%$ Off Variable \\
\hline Australia & 1 & 2,239 & 2 & 117.0 & 26.6 & 21.1 & Rates \\
\hline Energy Locals & 1,800 & 0 & 1,800 & 112.0 & 25.0 & 23.0 & $8 \%$ Off Total Bill \\
\hline Lumo Energy & - & - & - & 102.7 & 25.1 & 20.9 & $10 \%$ Off Total Bill \\
\hline Mojo Power & 1,200 & 200 & 1,000 & 179.1 & 22.6 & 17.4 & \\
\hline Momentum & $\begin{array}{c}17 \\
630,00\end{array}$ & $\begin{array}{c}7 \\
157,00\end{array}$ & $\begin{array}{c}10 \\
473,00\end{array}$ & 87.1 & 25.9 & 20.5 & $16 \%$ Off Variable \\
\hline Origin Energy & 0 & 0 & 0 & 117.0 & 24.5 & 20.5 & Rates \\
\hline PeopleEnergy & 0 & 0 & 0 & 116.4 & 22.2 & 18.9 & \\
\hline Powerdirect & 9,587 & 505 & 9,082 & 104.2 & 27.4 & 25.1 & $\begin{array}{l}14 \% \text { Off Variable } \\
\text { Rates }\end{array}$ \\
\hline Powershop & 6,181 & 0 & 6,181 & 104.2 & 26.8 & 25.1 & $16 \%$ Off Total Bill \\
\hline Qenergy & 1,751 & 475 & 1,276 & 120.0 & 30.6 & 28.6 & 17\% Off Total Bill \\
\hline $\begin{array}{l}\text { Red Energy } \\
\text { Sanctuary }\end{array}$ & 55,171 & 588 & 54,583 & 102.7 & 23.3 & 20.9 & $10 \%$ Off Total Bill \\
\hline $\begin{array}{l}\text { Energy } \\
\text { Simply }\end{array}$ & 1,550 & 100 & 1,450 & 131.1 & 24.5 & 20.8 & $20 \%$ Off Variable \\
\hline Energy & 14,403 & 23 & 14,380 & 89.9 & 28.0 & 25.4 & Rates \\
\hline TOTAL SEQ & $\begin{array}{c}1,317,9 \\
57 \\
640,00\end{array}$ & $\begin{array}{c}226,01 \\
8 \\
640,00\end{array}$ & & & & & \\
\hline Ergon Energy & $\begin{array}{c}0 \\
1,957,9\end{array}$ & $\begin{array}{c}0 \\
866,01\end{array}$ & $\begin{array}{c}0 \\
1,091,9\end{array}$ & 87.1 & 25.9 & 20.5 & \\
\hline TOTAL QLD & 57 & 8 & 39 & & & & \\
\hline
\end{tabular}

Source: Energy Retailers, Australian Energy Regulator (EnergyMadeEasy). **No response, estimated numbers.

Combining data from Table 6 and Figure 6 enables a view of price dispersion by customer numbers, in Figure 7. While there are technically 18 Offers exceeding Benchmark at $6250 \mathrm{kWh} / \mathrm{a}$, the actual number of customer above Benchmark is low. The ACCC (2017) flagged the highest cost tariff in their most recent report to media and policymakers; what they did not reveal is how few customers were actually exposed to it. 
Figure 7: $\quad$ Tariff dispersion by customer accounts vs Benchmark

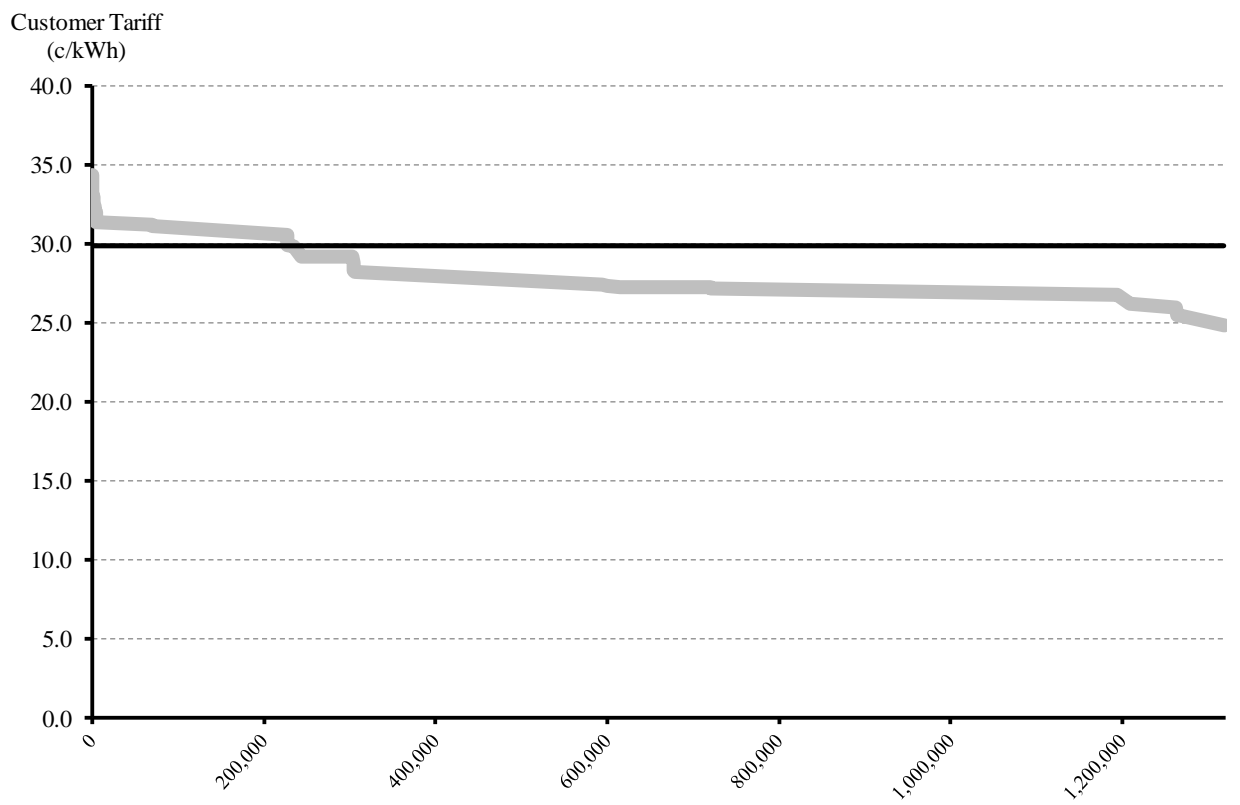

Combining market volumes with customer tariff data from Table 6 and Figure 7 enables a comparison of the regulated Regional Queensland market with the deregulated Southeast Queensland market. This analysis is presented in Table 7.

Table 7: Analysis of Regulated Regional vs. Deregulated Southeast Queensland

\begin{tabular}{rlccc}
\hline & & Regional Qld & Southeast Qld & Total Qld \\
\hline 1 & Tariff Status & Regulated & Deregulated & Mixed \\
2 & Customers & 640,000 & $1,317,957$ & $1,957,957$ \\
3 & Energy GWh & $4,000,000$ & $8,237,232$ & $12,237,232$ \\
4 & Energy Bills (\$ '000) & $1,195,879$ & $2,278,620$ & $3,474,498$ \\
5 & Benchmark (\$'000) & $1,195,879$ & $2,462,682$ & $3,658,561$ \\
6 & Gain (\$'000) & - & 184,063 & 184,063 \\
7 & Unit Price (c/kWh) & 29.90 & 27.66 & 28.39 \\
8 & Average Discount (\%) & - & $\mathbf{7 . 5 \%}$ & $5.0 \%$ \\
9 & Customers Above Benchmark & 0 & 227,398 & 227,398 \\
10 & Customers Below Benchmark & 0 & $1,037,104$ & $1,037,104$ \\
11 & Customers At Benchmark & 640,000 & 53,455 & 693,455 \\
\hline
\end{tabular}

Key results in Table 7 are lines 6 and 10 - the aggregate consumer welfare Gain from price deregulation is $\$ 184.0$ million, and aggregate customers numbers below Benchmark is $1,037,104$ households. In other words, the market has been successful at regulating overall average prices. Furthermore, a majority of households (i.e. 78.7\%) have benefited significantly from price deregulation, and consumers overall are better off.

\section{The modes of failure in deregulated retail electricity markets}

The analysis produced by the ACCC (2017, pp98-100) implied something was entirely amiss in Southeast Queensland but evidence contained in Section 3 indicates a well-functioning residential electricity market. This is not to suggest the market is free of failures. Certain issues identified in Thwaites et al (2017) vis-à-vis the deregulated Victorian market, and by the ACCC (2017), are serious policy problems that require ongoing policy adjustment, and further research. 
It is worth sifting through key market variables in order to distinguish genuine from perceived problems, and in turn, guide policymakers and Official Advisors towards dealing with legitimate modes of failure, and conversely, avoiding the catastrophic errors of Ofgem, viz. misdiagnosing functioning market characteristics as problems and designing policy to fix it, and in the process doing more harm than good.

\subsection{Jawboning: the role of the Department of Energy}

In Australia's NEM, energy market policy advice is a congested space. ${ }^{32}$ With a strange twist of irony as the electricity industry was reformed, utilities privatised and industry dynamics and general market complexity increased, the size and capacity of the average jurisdictional Department of Energy diminished and functions were abandoned - especially as markets were deregulated. Queensland's Department was subjected to these same trends over two decades, however, two functional areas remained sharply focused and well-resourced with highly capable teams: (1) Retail Markets \& Consumer Pricing, and (2) Wholesale Markets, along with a data analytics team providing requisite quantitative support.

This energy policy and analytical base provided the basis for Official Advice to government, but crucially, would also form the foundation of industry jawboning. Relying on the basic principals in Stigler \& Friedland (1962) - viz. that utilities fear the risk of re-regulation more than regulation itself - the Director-General and Deputy Director-General of the Queensland Department of Energy would routinely "call in" each incumbent retailer (separately for antitrust reasons) prior to the start of each financial year, and specifically, prior to each tariff change announcement. Pre-armed with the "house view" generated by Departmental teams and triangulated with the Regional Queensland regulated Benchmark, these "in-confidence" jawboning sessions ensured two things:

1. the Department could confidently explain to Government Ministers the precise basis of an incumbent retailer's Standing Offer tariff change (i.e. Year-on-Year \% change); and if not,

2. provide the incumbent retailer with sufficient time to go away and "think carefully and purposefully" and if necessary, moderate planned increases in order to satisfy 1).

In jawboning, the judgement of Official Advisors was also continually on trial - as a form of soft policy it worked only if Executive Government upheld an implicit bargain; viz. avoiding episodes of energy retailers being pilloried by Government Ministers in the media following announcement of their Standing Offer increase. In my professional experience ${ }^{33}$ when 1) was satisfied, Government Ministers proved very adept at minimising the adverse media and politics of Standing Offer changes.

Because industry participants understood the intended outcome of jawboning was ultimately a healthy marketplace with minimal distortionary and random political interventions, market participants seemed to appreciate and respond to timely insights provided by Official Advisors on Government thinking and the policy lens through which Government Ministers may view market performance. ${ }^{34}$

\subsection{Standing Offers and a counterfactual Benchmark}

Southeast Queensland appears to benefit from the transparent and independently determined Benchmark. While the methodology does not have universal support, it is helpful because it is consistently applied and provides guidance for what constitutes a fair and reasonable Year-

\footnotetext{
${ }^{32}$ NEM rulemaking is undertaken by the Australian Energy Market Commission, system operations is undertaken by the Australian Energy Market Operator, NEM regulatory enforcement is undertaken by the Australian Energy Regulator, state-based matters are frequently delegated to jurisdictional economic regulatory authorities (e.g. Queensland Competition Authority, Victorian Essential Services Commission) and Energy Ministers have political advisors along with their Energy Departments.

${ }^{33}$ The author was Director-General of the Department of Energy \& Water Supply from mid-2015 to late-2017. Mr Benn Barr was Deputy Director-General (Energy).

${ }^{34}$ It is worth noting that by contrast, in the experience of many market participants, and as far as I am aware - orchestrated, preemptive jawboning by Energy Departments and its implicit compact was not widely practiced.
} 
on-Year tariff change. It also has the unintended, but beneficial side-effect, of providing some degree of "cover" for incumbent retailer tariff changes. The test of usefulness will be under conditions of a falling tariff determination. Other NEM regions do not have an independent Benchmark or tariff index, but there is nothing stopping Energy Departments from creating a credible one in conjunction with industry participants.

\subsection{Market Confusion or Diversity of Offers?}

The application of a Benchmark needs to be used carefully. It will not be the ideal tariff. A common criticism of the market is rising complexity as Offer structures vary amongst retailers. This is not a policy problem - it is evidence of a workably competitive market. Occasionally, a regulator or policy advisor may be tempted to regulate the fixed component of the two-part tariff (or worse, ban fixed charges) in order to make comparison of retailer variable rates "easier". Ofgem pursued this concept in 2012 but quickly reversed direction presumably due to the sheer volume of dire warnings from industry, informed consumer groups and independent academic economists. Any attempt to do so will eliminate products, leaving some consumers considerably worse off, and consumers as a class no better off (Pollitt \& Haney, 2014; Littlechild, 2014).

Differences in tariff structure is how retailers attack rivals and steal customers (Simshauser \& Whish-Wilson, 2017). In an applied example, Tables 8-10 illustrate the rich variation in offers for small customers $\left(20^{\text {th }}\right.$ percentile $)$ and large customers $\left(80^{\text {th }}\right.$ percentile). Note in Table 8 that Red Energy's $10 \%$ Off The Bill is the best available offer for a $20^{\text {th }}$ percentile customer, followed by Qenergy. Table 10 illustrates that Alinta Energy's 25\% Off Variable Rates is the lowest cost offer for an $80^{\text {th }}$ percentile customer.

\subsection{Reference Rates: consumer trust and the "discount off what?" problem}

An issue that has bedevilled NEM institutional bodies, Official Advisors and a cause of considerable consternation amongst consumer groups has been the lack of a market "reference rate" from which to anchor discounts, and the different ways in which discounts are structured. The complexity that exists is the non-linearity of tariffs and diversity of customer consumption levels. In the absence of a formal reference rate, retailer discounts become "unanchored" - colloquially known as the "discount off what?" problem.

For example, recall from Table 6 that Click Energy's discounted product is marketed as " $22 \%$ Off the Total Bill". This is a very competitive apparent discount rate relative to all other Market Offers. But for the reference customer, Click Energy's Standing Offer is 14.8\% above Benchmark, and thus a 22\% discount of an elevated Standing Offer quickly diminishes down to a mere $2.5 \%$ discount. However, Click Energy has the market's most competitive solar PV Feed-in Tariff - which is evidently their target market and extending the analysis to large solar households will reveal markedly improved customer outcomes.

To further illustrate the discounts off what? problem, Tables 8-10 rank the top 10 Market Offers for small $(1610 \mathrm{kWh})$, reference $(6250 \mathrm{kWh})$ and large $(8431 \mathrm{kWh})$ customers, respectively. Notice in Table 8 that the best deal for small customers is Red Energy's " $10 \%$ Off the Total Bill" (Table 8, Line 1) followed by Qenergy's which is marked as "17\% Off the Total Bill” (Line 2), noting Qenergy's Standing Offer is 7.3\% higher than Red Energy's. Other retailers do not provide a discount off the total bill, but rather, the variable rate only (thus leaving the fixed charge at the Standing Offer rate.

Alinta's "25\% Off Variable Rates" (Table 8, Line 3) has a very high headline discount, but because it is structured as a discount to variable rates the apparent gains to small consumers are smaller. However, this same product proves to be the most competitive in the market for reference (Table 9) and large (Table 10) customers. Indeed, by comparison to Table 8 small customers, for the reference $(6250 \mathrm{kWh})$ customer the rank order of the best three Market Offers reverses, with Alinta Energy (Table 9, Line 1) being the most competitive, followed by Qenergy (Line 2) and Red Energy (Line 3). By way of another example, Dodo Power \& 
Gas's Market Offer is very competitive for Reference customers (Table 9, Line 4) and large customers (Table 10, Line 3 ) but does not make the Top 10 for small customers.

Table 8: Discounts off what? Annual bill for a small customer $\left(20^{\text {th }}\right.$ percentile $) 1610 \mathrm{kWh}$ pa

\begin{tabular}{|c|c|c|c|c|c|c|c|}
\hline & $\begin{array}{c}\text { Fixed } \\
\text { Daily } \\
\text { Char } \\
\text { ge } \\
\text { (c/da } \\
\text { y) }\end{array}$ & $\begin{array}{c}\text { Variab } \\
\text { le } \\
\text { Rate } \\
\text { for } \\
\text { T11 } \\
\text { (c/kW } \\
\text { h) }\end{array}$ & $\begin{array}{c}\text { Variab } \\
\text { le } \\
\text { Rate } \\
\text { for } \\
\text { T33 } \\
(\mathrm{c} / \mathrm{kW} \\
\mathrm{h}) \\
\end{array}$ & Routine Discount & $\begin{array}{c}\text { Annual } \\
\text { Cost at } \\
1610 \mathrm{k} \\
\text { Wh } \\
(\$ / \mathrm{a}) \\
\end{array}$ & $\begin{array}{c}\text { Diff. } \\
\text { from } \\
\text { Benchm } \\
\text { ark } \\
\text { (\$/a) }\end{array}$ & $\begin{array}{c}\text { Diff. } \\
\text { from } \\
\text { Benchm } \\
\text { ark } \\
\\
(\%) \\
\end{array}$ \\
\hline Benchmark & 87.1 & 25.9 & 20.5 & & $\$ 717$ & $\$ 0$ & 0.0 \\
\hline Red Energy & 102.7 & 23.3 & 20.9 & $10 \%$ Off Total Bill & $\$ 668$ & $-\$ 50$ & 6.9 \\
\hline $\begin{array}{l}\text { Qenergy } \\
\text { Alinta }\end{array}$ & 120.0 & 30.6 & 28.6 & $\begin{array}{l}\text { 17\% Off Total Bill } \\
25 \% \text { Off Variable }\end{array}$ & $\$ 674$ & $-\$ 44$ & 6.1 \\
\hline Energy & 101.8 & 26.0 & 22.0 & Rates & $\$ 676$ & $-\$ 42$ & 5.8 \\
\hline $\begin{array}{l}\text { Powershop } \\
\text { Simply }\end{array}$ & 104.2 & 26.8 & 25.1 & $\begin{array}{l}16 \% \text { Off Total Bill } \\
20 \% \text { Off Variable }\end{array}$ & $\$ 677$ & $-\$ 40$ & 5.6 \\
\hline $\begin{array}{l}\text { Energy } \\
\text { Lumo }\end{array}$ & 89.9 & 28.0 & 25.4 & Rates & $\$ 682$ & $-\$ 35$ & 4.9 \\
\hline Energy & 102.7 & 25.1 & 20.9 & $10 \%$ Off Total Bill & $\$ 688$ & $-\$ 29$ & 4.1 \\
\hline $\begin{array}{l}\text { Momentum } \\
\text { AGL }\end{array}$ & 87.1 & 25.9 & 20.5 & $15 \%$ Off Variable & $\$ 717$ & $\$ 0$ & 0.0 \\
\hline $\begin{array}{l}\text { Energy } \\
\text { Energy }\end{array}$ & 103.0 & 26.0 & 22.0 & Rates & $\$ 721$ & $\$ 3$ & -0.5 \\
\hline Locals & 112.0 & 25.0 & 23.0 & $\begin{array}{l}8 \% \text { Off Total Bill } \\
15 \% \text { Off Variable }\end{array}$ & $\$ 734$ & $\$ 16$ & -2.2 \\
\hline Amaysim & 120.0 & 27.7 & 25.8 & Rates & $\$ 746$ & $\$ 28$ & -3.9 \\
\hline
\end{tabular}

Table 9: Discounts off what? Annual bill for reference customer $6250 \mathrm{kWh}$ pa

\begin{tabular}{|c|c|c|c|c|c|c|c|}
\hline & $\begin{array}{c}\text { Fixe } \\
\text { d } \\
\text { Dail } \\
\text { y } \\
\text { Char } \\
\text { ge } \\
\text { (c/da } \\
\text { y) }\end{array}$ & $\begin{array}{c}\text { Varia } \\
\text { ble } \\
\text { Rate } \\
\text { for } \\
\mathrm{T} 11 \\
(\mathrm{c} / \mathrm{kW} \\
\mathrm{h})\end{array}$ & $\begin{array}{c}\text { Varia } \\
\text { ble } \\
\text { Rate } \\
\text { for } \\
\mathrm{T} 33 \\
\text { (c/kW } \\
\text { h) }\end{array}$ & Routine Discount & $\begin{array}{c}\text { Annual } \\
\text { Cost at } \\
6250 \mathrm{k} \\
\text { Wh } \\
(\$ / \mathrm{a}) \\
\end{array}$ & $\begin{array}{c}\text { Diff. } \\
\text { from } \\
\text { Benchm } \\
\text { ark } \\
\\
(\$ / \mathrm{a})\end{array}$ & $\begin{array}{c}\text { Diff. } \\
\text { from } \\
\text { Benchm } \\
\text { ark } \\
(\%) \\
\end{array}$ \\
\hline Benchmark & $\begin{array}{l}87.1 \\
101 .\end{array}$ & 25.9 & 20.5 & $25 \%$ Off Variable & $\$ 1,869$ & $\$ 0$ & 0.0 \\
\hline Alinta Energy & $\begin{array}{c}8 \\
120 .\end{array}$ & 26.0 & 22.0 & $\begin{array}{c}\text { Rates } \\
17 \% \text { Off Total }\end{array}$ & $\$ 1,553$ & $-\$ 316$ & 16.9 \\
\hline Qenergy & $\begin{array}{c}0 \\
102 .\end{array}$ & 30.6 & 28.6 & $\begin{array}{c}\text { Bill } \\
10 \% \text { Off Total }\end{array}$ & $\$ 1,593$ & $-\$ 275$ & 14.7 \\
\hline $\begin{array}{l}\text { Red Energy } \\
\text { Dodo Power }\end{array}$ & $\begin{array}{c}7 \\
121\end{array}$ & 23.3 & 20.9 & $\begin{array}{c}\text { Bill } \\
25 \% \text { Off Variable }\end{array}$ & $\$ 1,620$ & $-\$ 248$ & 13.3 \\
\hline$\&$ Gas & $\begin{array}{c}9 \\
117 .\end{array}$ & 26.3 & 22.3 & $\begin{array}{c}\text { Rates } \\
16 \% \text { Off Variable }\end{array}$ & $\$ 1,638$ & $-\$ 231$ & 12.3 \\
\hline Origin Energy & $\begin{array}{c}0 \\
102 .\end{array}$ & 24.5 & 20.5 & $\begin{array}{c}\text { Rates } \\
10 \% \text { Off Total }\end{array}$ & $\$ 1,671$ & $-\$ 197$ & 10.6 \\
\hline $\begin{array}{l}\text { Lumo Energy } \\
\text { Energy }\end{array}$ & $\begin{array}{c}7 \\
117 .\end{array}$ & 25.1 & 20.9 & $\begin{array}{c}\text { Bill } \\
20 \% \text { Off Variable }\end{array}$ & $\$ 1,699$ & $-\$ 169$ & 9.1 \\
\hline Australia & 0 & 26.6 & 21.1 & Rates & $\$ 1,701$ & $-\$ 168$ & 9.0 \\
\hline Simply & 89.9 & 28.0 & 25.4 & $20 \%$ Off Variable & $\$ 1,703$ & $-\$ 166$ & 8.9 \\
\hline
\end{tabular}


Energy

Rates

\begin{tabular}{|c|c|c|c|c|c|c|c|}
\hline Powershop & $\begin{array}{c}104 . \\
2 \\
103 .\end{array}$ & 26.8 & 25.1 & $\begin{array}{l}\text { 16\% Off Total } \\
\text { Bill } \\
15 \% \text { Off Variable }\end{array}$ & $\$ 1,709$ & $-\$ 160$ & 8.6 \\
\hline AGL Energy & 0 & 26.0 & 22.0 & Rates & $\$ 1,715$ & $-\$ 154$ & 8.2 \\
\hline
\end{tabular}

Table 10: Discounts off what? Annual bill for a large customer $\left(80^{\text {th }}\right.$ percentile $) 8431 \mathrm{kWh}$ pa

\begin{tabular}{|c|c|c|c|c|c|c|c|}
\hline & $\begin{array}{c}\text { Fixe } \\
\text { d } \\
\text { Dail } \\
\text { y } \\
\text { Char } \\
\text { ge } \\
\text { (c/da } \\
\text { y) }\end{array}$ & $\begin{array}{l}\text { Varia } \\
\text { ble } \\
\text { Rate } \\
\text { for } \\
\text { T11 }\end{array}$ & $\begin{array}{c}\text { Varia } \\
\text { ble } \\
\text { Rate } \\
\text { for } \\
\text { T33 } \\
\text { (c/kW } \\
\text { h) }\end{array}$ & Routine Discount & $\begin{array}{c}\text { Annual } \\
\text { Cost at } \\
8431 \mathrm{k} \\
\text { Wh } \\
(\$ / \mathrm{a}) \\
\end{array}$ & $\begin{array}{l}\text { Diff. } \\
\text { from } \\
\text { Benchm } \\
\text { ark } \\
\text { (\$/a) }\end{array}$ & $\begin{array}{c}\text { Diff. } \\
\text { from } \\
\text { Benchm } \\
\text { ark } \\
\\
(\%)\end{array}$ \\
\hline Benchmark & $\begin{array}{l}87.1 \\
101 .\end{array}$ & 25.9 & 20.5 & $25 \%$ Off Variable & $\$ 2,410$ & $\$ 0$ & 0.0 \\
\hline Alinta Energy & $\begin{array}{c}8 \\
120 .\end{array}$ & 26.0 & 22.0 & $\begin{array}{c}\text { Rates } \\
\text { 17\% Off Total }\end{array}$ & $\$ 1,965$ & $-\$ 445$ & 18.5 \\
\hline $\begin{array}{l}\text { Qenergy } \\
\text { Dodo Power }\end{array}$ & $\begin{array}{c}0 \\
121 .\end{array}$ & 30.6 & 28.6 & $\begin{array}{c}\text { Bill } \\
25 \% \text { Off Variable }\end{array}$ & $\$ 2,026$ & $-\$ 384$ & 15.9 \\
\hline$\&$ Gas & $\begin{array}{c}9 \\
102 .\end{array}$ & 26.3 & 22.3 & $\begin{array}{c}\text { Rates } \\
10 \% \text { Off Total }\end{array}$ & $\$ 2,054$ & $-\$ 355$ & 14.7 \\
\hline Red Energy & $\begin{array}{c}7 \\
117 .\end{array}$ & 23.3 & 20.9 & $\begin{array}{l}\text { Bill } \\
16 \% \text { Off Variable }\end{array}$ & $\$ 2,068$ & $-\$ 342$ & 14.2 \\
\hline $\begin{array}{l}\text { Origin Energy } \\
\text { Energy }\end{array}$ & $\begin{array}{c}0 \\
117 .\end{array}$ & 24.5 & & $\begin{array}{l}\text { Rates } \\
20 \% \text { Off Variable }\end{array}$ & $\$ 2,106$ & $-\$ 304$ & 12.6 \\
\hline Australia & $\begin{array}{c}0 \\
102 .\end{array}$ & 26.6 & & $\begin{array}{c}\text { Rates } \\
\text { 10\% Off Total }\end{array}$ & $\$ 2,145$ & $-\$ 264$ & 11.0 \\
\hline Lumo Energy & $\begin{array}{c}7 \\
103 .\end{array}$ & & & $\begin{array}{l}\text { Bill } \\
\text { 15\% Off Variable }\end{array}$ & $\$ 2,174$ & $-\$ 235$ & 9.8 \\
\hline $\begin{array}{l}\text { AGL Energy } \\
\text { Simply }\end{array}$ & 0 & 26.0 & 22.0 & $\begin{array}{c}\text { Rates } \\
20 \% \text { Off Variable }\end{array}$ & $\$ 2,182$ & $-\$ 228$ & 9.5 \\
\hline Energy & $\begin{array}{l}89.9 \\
104 .\end{array}$ & 28.0 & 25.4 & $\begin{array}{c}\text { Rates } \\
\text { 16\% Off Total }\end{array}$ & $\$ 2,183$ & $-\$ 227$ & 9.4 \\
\hline Powershop & 2 & 26.8 & 25.1 & Bill & $\$ 2,194$ & $-\$ 216$ & 9.0 \\
\hline
\end{tabular}

Because tariffs are non-linear, a single reference rate or Benchmark based on an average customer will prove misleading for small customers or large customers, as the analysis above explains. ${ }^{35}$ This characteristic of the retail energy market is increasingly testing the confidence of policymakers and consumer groups in the market and their trust large energy retailers. The Australian Energy Regulator's website EnergyMadeEasy enables households to enter a few basic details, and then stacks the various Offers according to set criteria (e.g. lowest cost, highest Feed-in Tariff etc). The Regulator has thus far been reluctant to establish a reference rate, primarily to avoid the risk of partial re-regulation. This remains an area for further research.

\footnotetext{
${ }^{35}$ Thwaites et al. (2017) suggest establishing three reference volumes (small, medium and large consuming households) and reference rates from which to anchor discounts. This suggestion is prima facie sensible, although with solar PV, ripple control metering and other emerging developments such as Electric Vehicles and Batteries, three reference volumes quickly and necessarily expands to 10-20 reference volume combinations to accommodate consumer preferences for solar export meters (i.e. to access FiT), and controllable load metering for hot-water and pool pumps (Tariffs 31 and 33) and yet to be designed tariffs for EVs and Battery Storage.
} 


\subsection{Rising price dispersion}

Price discrimination and rising dispersion of prices is not a mode of failure. The theoretical and applied literature and evidence from other markets show this to be consistent with market participants responding to heightened competition. As Table 7 demonstrates, competition is a better form of consumer protection than regulation. Indeed, the doubling of consumer electricity prices in Queensland and other regions from 2007-2014 was driven by rising network charges; regulation of network prices failed spectacularly. Conversely, the competitive segments of the market, generation and retailing, are the reason that discounts below Benchmark exist in the first place.

Above all, attempts to stamp out the practice of price discrimination, including misguided calls by Prime Ministers to move "all customers onto the cheapest available tariff" can be relied on to achieve one crucial outcome - the elimination of deep discounts (see Hviid \& Waddams Price, 2012; Pollitt \& Haney, 2014; Littlechild, 2014, 2016).

There is, however, the substantive issue of consumer trust and confidence in the underlying behaviour or Energy Retailers, and the way in which their Market Offers are presented, and conditions which they attach, and the treatment of the mass market.

\subsection{Best price or better price?}

Thwaites et al. (2017) observed the best Market Offers in Victoria require consumers to switch regularly and remain engaged, that challenges exist in finding the best Offer, and benefits deteriorate sharply if the second, third or fourth best offer is selected. These characteristics were classed as failures and formed part of the justification for a stripped-back tariff or Basic Service Offer.

That consumers need to remain engaged in a market, any market, to secure good deals should come as no surprise to policymakers and does not warrant policy intervention. Other essential consumables like bottled milk are very cheap at Supermarkets and very expensive at 24-hour convenience stores, but this does not represent a failed market. Vulnerable customers aside, consumers should be trusted to make adult decisions ${ }^{36}$ with the different electricity retailers and their different business models and products.

The suggestion that 'benefits deteriorate sharply' with the second, third and fourth-best offer is not supported by the evidence in Tables 8-10. If there is a large variation between first- and remaining rival offers it is more likely to reflect a retailer trying to enter a market or marketsegment, claw-back lost customers prior to announcing year-end results to the stock exchange, or a retailer seeking to unwind an over-hedged position; rather than 19 uncompetitive and incompetent rivals. Moreover, electricity tariffs are non-linear, consequently, the best Market Offer for a $1610 \mathrm{kWh} / \mathrm{a}$ customer is most unlikely to be the best Market Offer for an 8,431kWh/a customer as Tables 8-10 demonstrate.

Furthermore, measuring the second, third, and fourth-best offers and above as sub-optimal and comprising an apparent failed market by comparison to the lowest available offer is disingenuous. It fails to distinguish legitimate producer surplus (i.e. recovery of sunk capital, operating and overhead costs), normal from supranormal profits, retail-only from legitimate vertical-retailer costs, and overlooks the array of conditions and services available to consumers with rival products. In Southeast Queensland, welfare agencies routinely direct vulnerable customers to either of the two incumbent retailers, Origin Energy and AGL Energy, due to their 24-hour call centres, known levels of customer service, payment flexibility and completeness of hardship schemes.

\footnotetext{
${ }^{36}$ Indeed, as Littlechild (2014) has previously argued, policymakers and their advisors seem to trust consumers to make enormous financial commitments on other essentials. Household expenditure data from the Australian Bureau of Statistics reveals that for Australians, this includes housing (18.62\% of household income), food (16.09\% of household income) and telecommunications $(2.59 \%$ of household income) yet fear the same households are unable to navigate the procurement of electricity (2.17\% of household income). Source: Australian household expenditure data from Australian Bureau of Statistics at http://www.abs.gov.au/AUSSTATS/abs@.nsf/DetailsPage/6473.0Sep\%202017?OpenDocument
} 
With the notable exception of vulnerable households, it is not the role of policymakers or Official Advisors to construct policy that ensure customers are on the best available tariff. Policymakers have a responsibility to ensure an orderly, transparent and workably competitive market. Product selection is the responsibility of consumers. As the head of energy policy at St Vincent de Paul has said to the author on any number of occasions, "consumers should simply aim to get on a better deal, not torture themselves trying to find the absolute best deal".

\subsection{Inter-consumer misallocation problem}

Of all the issues facing policymakers with deregulated residential electricity markets, the inter-consumer misallocation problem is, in my opinion, the most important and worthy of attention from both industry and policymakers alike. As an essential service, policymakers cannot allow a deregulated electricity market to injure households. Corporates must respect this simple proposition and work with policymakers and Official Advisors. Resolution requires simple remedies. This was the focus of Simshauser \& Whish-Wilson (2017) - if Standing Offers of incumbent retailers drift above a counterfactual 'Benchmark' and if any customers on that Standing Offer also have a welfare flag (i.e. vulnerable), that group of customers should be automatically transferred to a discounted product competitive with Benchmark. A "no action" agreement from regulatory authorities is important; customers cannot be assigned to a new product without their Explicit Informed Consent - but in these circumstances there is an unambiguous welfare improvement and as such regulatory authorities should support the change.

\section{Concluding remarks}

The policy of price deregulation in residential electricity markets has come under sharp focus in two of the pioneering jurisdictions, Great Britain and Victoria. Central to regulatory and policymaker concern has been the apparent fairness arising from third-degree price discrimination. However, in both Great Britain and Victoria, general electricity prices had been increasing sharply in prior periods.

Sharply rising electricity prices are a problem. Third degree price discrimination is not. There is nothing inherently unfair about price discrimination in workably competitive markets; on the contrary, it is frequently welfare enhancing - especially in heavy industries and efforts to stamp out the practice are likely to do more harm than good. Evidence from Great Britain is that it inflamed prices.

In this article, Queensland was analysed due to its unique characteristic of a single wholesale region with the two extremities of retail markets, viz. a fully contestable and deregulated retail market (Southeast Queensland) sitting along-side a fully regulated monopoly supplier (Regional Queensland). The deregulated market is evoling in a manner consistent with the literature; as price controls were removed the number of rivals increased from 12 to 20, products and tariff structures proliferated, routine discounts deepened, customer switching rates increased sharply, and price dispersion increased materially by comparison to the prederegulated contestable market, let alone the uniform-priced regulated regional market.

Unlike Victoria, price dispersion in Southeast Queensland has not arisen as a political focus event even though the distance between the highest Standing Offer and deepest discount is equivalent to Victoria, i.e. 35\%. This article has argued two key parameters helped in this regard. First, industry jawboning by the Queensland Department of Energy ensured tariff changes by incumbents were explainable, and triangulated with the Department's "house view" and the Year-on-Year change in the Benchmark. And second, the presence of a transparent and independently determined Benchmark tariff used in the adjacent regulated monopoly service area.

Above all, quantitative analysis presented in this article found a majority (78.9\%) of Southeast Queensland electricity consumers have benefited from deregulation, some significantly, and consumers as a whole are substantially better off. The competitive market 
has been successful at regulating overall average prices. Some Standing Offers have risen above the counterfactual Benchmark, and this means two key issues will require monitoring; 1). the inter-consumer misallocation problem (i.e. vulnerable customers rusted-on to a Standing Offer tariff designed for strong segment consumers), and 2). the "discounts off what?" problem. With a rising dispersion and volume of Standing Offer tariffs, discounted products can be misleading and the problem here is an obvious one. If a retailer offers an $18 \%$ discounted product immediately after increasing their Standing Offer by $18 \%$, what discount is the customer actually receiving? Resolving the former matter is relatively straight forward via moving vulnerable customers onto a Benchmark-equivalent discounted tariff. Due to the non-linearity of tariffs and the rising mix of discrete metered loads, the latter requires more research.

\section{References}

Armstrong, M., 2006a, "Recent Developments in the economics of price discrimination", in R.Blundell, W. Newey, and T. Persson, (ed.), Advances in Economics and Econometrics: Theory and Applications: Ninth World Congress of the Econometrics: Theory and Applications. Ninth World Congress of the Econometric Society, Cambridge University Press, Cambridge.

Armstrong, M. 2006b, "Price discrimination", (mimeo), Department of Economics, University College London. Available at http://else.econ.ucl.ac.uk/papers/uploaded/222.pdf (Accessed January 2015).

Armstrong, M., 2008, "Price Discrimination", in P. Buccirossi (ed.) Handbook of Antitrust Economics, The MIT Press, Cambridge, MA.

Averch, H. and Johnson, L. (1962), "Behaviour of the firm under regulatory constraint", American Economic Review, 52(1): 1052-1069.

Baumol, W. \& Swanson, D. 2003. "The new economy and ubiquitous competitive price discrimination: Identifying defensible criteria of market power", Antitrust Law Journal, 70(3): 661-85.

Ben-David, R. 2013. "Regulating retail electricity markets in the long-term interests of consumers", Proceedings from the Power \& Pricing Conference, Melbourne 23 May 2013. Available at: http://escdev.grindstone.com.au/wp-content/uploads/esc/13/13504356-46aa-4d94-b3d2-93db96aa6f9f.pdf (accessed June 2015).

Ben-David, R. 2015. "If the retail energy market is competitive then is Lara Bingle a Russian cosmonaut?", Available at: http://www.esc.vic.gov.au/getattachment/fc947897-7d4f-4772-97c9959e3baad0db/If-the-retail-energy-market-is-competitive-then-is.pdf_(accessed June 2015).

Bester, H., and E. Petrakis, 1996, "Coupons and Oligopolistic Price Discrimination”, International Journal of Industrial Organization, 14(2), 227-242.

Boiteux, M. (1949). "La tarification des demandes en pointe: Application de la theorie de la vente au cout marginal", Revue Generale de l'Electricite, Translated by H. Izzard in Journal of Business, Boiteux, M. 1960, 'Peak load pricing', Journal of Business, Vol.33, No.2, pp. 157-80.

Bonbright, J. (1961). “Principles of Public Utility Rates”, Columbia University Press, New York.

Borenstein, S. 1985. "Price discrimination in free-entry markets", RAND Journal of Economics 16(3): 380-397.

Borenstein, S. (2013), "Effective and equitable adoption of opt-in residential dynamic electricity pricing", Review of Industrial Organisation, 42(2): 127-160. doi:10.1007/s11151-012-9367-3.

Borenstein, S. and Holland, S. (2005), "On the efficiency of competitive markets with time-invariant retail prices", RAND Journal of Economics, 36(3): 469-493.

Borenstein, S. and Rose, N. 1994. "Competition and price dispersion in the U.S. airline industry", Journal of Political Economy, 102(4): 653-683. 
Buckman, G. and Diesendorf, M. 2010, "Design limitations in Australian renewable electricity policies”, Energy Policy, 38(2010): 3365-3376.

Bunzl, M. 2010, Is flat fair? The Electricity Journal, 23(6): 8-12.

Chen, Y. 1997, "Paying Customers to Switch", Journal of Economics and Management, 6(4): 877-897.

Chen, Y. 2006, "Dynamic price discrimination with asymmetric firms", Department of Economics University of Colorado. Available at http://stripe.colorado.edu/ cheny/research/Dynamic-PDJune06.pdf (Accessed June 2015).

Clark, J.M. 1911. "Rates for Public Utilities”, American Economic Review, 1(3): 473-487.

CMA (2016) Energy Market Investigation: Summary of Final Report. London: CMA. Available at https://www.gov.uk/cma-cases/energy-market-investigation\#final-report (accessed December 2017).

CME: Carbon Market Economics, 2015, "A critique of the Victorian retail electricity market: a report for the Brotherhood of St Laurence”, CME Publication, Melbourne.

Coase, R. 1946. “The Marginal Cost Controversy” Economica, 13(51): 169-182.

Corts, K. 1998. "Third-degree price discrimination in oligopoly: All-out competition and strategic commitment”, RAND Journal of Economics, 29(2): 306-323.

Crew, M. and Kleindorfer, P. 1976, "Peak load pricing with a diverse technology", Bell Journal of Economics, 7(1): 207-231.

Dana Jr., J.D. 1998. “Advance-purchase discounts and price discrimination in competitive markets”, Journal of Political Economy, 106(2), 395-422.

Dana Jr., J.D. 1999a. "Using yield management to shift demand when the peak time is unknown", RAND Journal of Economics 30(3), 456-474.

Dana Jr., J.D. 1999b, "Equilibrium price dispersion under demand uncertainty: The roles of costly capacity and market structure", RAND Journal of Economics, 30(4), 632-660.

Dessus, G. 1949, "Les principles generaux de la tarification dans les services publics", Union Internationale des Producteurs et Distributeurs de 'Energie Electrique, Paper VI, pp5-20. Translated in Dessus, G. 1951, "The general principles of rate fixing in public utilities", International Economic Papers, Vol.1, pp. 5-22.

Dobson, P., \& M. Waterson, 2005. “Chain-Store Pricing Across Local Markets”, Journal of Economics and Management Strategy, 14(1), 93-119.

Dufty, G. and Johnson, M. 2014, "NEM wrong way go back?”, St Vincent de Paul Society, Melbourne. Available at: https://www.vinnies.org.au/icms_docs/195912_2014_September_-

_Wrong_Way_Go_Back.pdf (accessed June 2015).

Dupuit, J. 1844, "On the measurement of the utility of public works", translated in International Economic Papers, 2(1952): 83-110, by RH Barback from "De la mesure de l'Utilite des Travaux Publics”, Annales des Ponts et Chaussees, 2d series, 8(1844).

Elegido, J. 2011, “The ethics of price discrimination”, Business Ethics Quarterly, 21(4): 633-660.

Energex \& Ergon (2014), “Are Queensland Residents Willing and Able to Respond to Time Varying Electricity Prices?”, Australian Economic Review, 47(3): 324-346. doi:10.1111/1467-8462.12063.

ESC: Essential Services Commission of Victoria, 2013, "Retailer margins in Victoria's electricity market", Discussion Paper, ESC, Melbourne. Available at:

http://www.esc.vic.gov.au/getattachment/18cdbfc4-107b-497a-ab59-6cce797957c7/Electricity-RetailMargins-Discussion-Paper.pdf (Accessed 16 June 2015).

Esteves, R. 2009, “Customer poaching and advertising”, Journal of Industrial Economics, 57: 112-146. 
Faruqui, A. 2010a, "The ethics of dynamic pricing", The Electricity Journal, 23(6): 13-27.

Faruqui, A. 2010b, "Residential dynamic pricing and energy stamps", Regulation, Winter, pp 4-5.

Faruqui, A. \& Malko, J, 1983, "The residential demand for electricity by time-of-use: a survey of 12 experiments with peak load pricing", Energy, 8(10): 781-795.

Faruqui, A. and Sergici, S. 2010, "Household response to dynamic pricing of electricity: a survey of 15 experiments", Journal of Regulatory Economics, 38(2): 194-225.

Faruqui, A. and Sergici, S. 2013, "Arcturus: international evidence on dynamic pricing”, The Electricity Journal, 26(7): 55-66.

Faruqui, A., Sergici, S. and Sharif, A. 2010, "The impact of informational feedback on energy consumption - a survey of the experimental evidence", Energy, 35(4): 1598-1608.

Felder, F. 2010, The practical equity implications of advanced metering infrastructure, The Electricity Journal, 23(6): 56-64.

Fenwick, S., Getachew, L., Ivanov, C. and Smith, J. 2014, "Demand impact of a critical peak pricing program: opt-in and opt-out options, green attitudes and other customer characteristics", The Energy Journal, 35(3): 1-24.

Flores M. and Waddams Price, C. 2018, "The Role of Attitudes and Marketing in Consumer Behaviours in the British Retail Electricity Market”, The Energy Journal, 39(4): 153-179.

Freebairn, J. 2014, "Carbon price versus subsidies to reduce greenhouse gas emissions", Economic Papers, 33(3): 233-242.

Grattan (2017), "Price shock: Is the retail electricity market failing consumers?", Grattan Institute Publication, Melbourne. Available at https://grattan.edu.au/report/price-shock/ (viewed January 2018).

Giulietti, M., Waddams Price, C. \& Waterson, M. 2005. Consumer Choice and Competition Policy: a Study of UK Energy Markets. The Economic Journal 115(506): 949-968.

Green, R. 2012, “Ofgem's Consultation on the undue discrimination prohibition standard licence condition", 10 April 2012.

Hausman, W. \& Neufeld, J. 1989. "Engineers and Economists: Historical Perspectives on the Pricing of Electricity", Technology and Culture, 30(1): 83-104.

He, X. and Reiner, D. 2017, "Why consumers switch energy suppliers: the role of individual attitudes", The Energy Journal, 38(6): 25-53.

Holmes, T. 1989. "The effects of third-degree price discrimination in oligopoly", American Economic Review, 79: 244-250.

Hotelling, H. 1938. "The General Welfare in Relation to Problems of Taxation and of Railway and Utility Rates", Econometrica, 6(3): 242-269.

Houthakker, H. (1951), "Electricity Tariffs in Theory \& Practice", The Economic Journal, 61(241):125. doi: $10.2307 / 2226608$.

Hviid, M. and Waddams Price, C. 2012, "Non-discrimination clauses in the retail energy sector", The Economic Journal, Vol 122 (August): F236-F252.

Hviid, M. and Waddams Price, C. 2014, "Well-functioning markets in retail energy", European Competition Journal, 10(1): 167-179.

IPART: Independent Pricing \& Regulatory Tribunal, 2013, "Review of regulated retail prices for electricity, 2013-2016", IPART Publication, Sydney. 
Jones, S. 2009, “The future of renewable energy in Australia: a test for cooperative federalism?”, Australian Journal of Public Administration, 68(1): 1-20.

Joskow, P. 1976. "Contributions to the theory of marginal cost pricing”, Bell Journal of Economics, 7(1): 197-206.

Joskow, P. 2010. Vertical integration. Antitrust Bulletin, 55(3), 545-586.

Katz, M. L. 1984, "Price discrimination and monopolistic competition", Econometrica, 52(1984): 1453-1471.

Klein, B. 1993, "Market power in antitrust: economic analysis after Kodak", Supreme Court Economic Review, 3(1993): 43-92

Kydland, F. and Prescott, E. (1977), "Rules rather than discretion: the inconsistency of optimal plans", The Journal of Political Economy, 85(3): 473-492.

Levine, M. E. 2002. Price discrimination without market power. Yale Journal on Regulation, 19: 1-36.

Lewis, A. 1941. "The two-part tariff”, Economica, 8(31): 249-270.

Littlechild, S. 2014, "Promoting or restricting competition? Regulation of the UK residential electricity market since 2008”, EPRG Working Paper No. 1415, University of Cambridge.

Littlechild, S. 2016, “Contrasting developments in UK energy regulation: retail policy and consumer engagement”, Economic Affairs, 36(2): 118-132.

Littlechild, S. 2016b, "The CMA energy market investigation, the well-functioning market, Ofgem, Government and behavioural economics", European Competition Journal, 11(2-3): 574-636.

Littlechild, 2017, "Competition and price controls in the UK retail energy market", Network, Issue 63(June): 1-11.

MacGill, I. 2010. "Electricity market design for facilitating the integration of wind energy: experience and prospects with the Australian National Electricity Market", Energy Policy, 38(2010): 3180-3191.

Marcoux, A. M. 2006. "Much ado about price discrimination", Journal of Markets and Morality, 9(1): 57-69

Matutes, C., \& Regibeau, P. 1992. "Compatibility and Bundling of Complementary Goods in a Duopoly,” Journal of Industrial Economics, 40(1): 37-54.

Nelson, J. (1964) (Ed.), "Marginal Cost Pricing in Practice”, Prentice Hall Inc, Englewood Cliffs.

Nelson, T., Simshauser, P. \& Nelson, J. 2012, "Queensland solar Feed-in Tariffs and the merit-order effect: economic benefit or regressive taxation and wealth transfers?”, Economic Analysis \& Policy, 42(3): 277-301.

Nelson, T., Nelson, J., Ariyaratnam, J. and Camroux, S. 2013, “An analysis of Australia's large scale renewable energy target: restoring market confidence", Energy Policy, 62(2013): 386-400.

Ofgem, 2008, Energy Supply Probe - Initial Findings Report, 140/08, 6 October 2008.

Ofgem, 2011, Retail Market Review - Findings and initial proposals, Ref 34/11, March 2011.

Olsen, W. 2012, "Fairness, Financial autonomy and independence: lessons from regulated industries", The Electricity Journal, 25(1): 57-68.

Pigou, A.C. 1920, The economics of welfare, Macmillan, London.

Pollitt, M. and Haney, A. 2014, "Dismantling a competitive retail electricity market: residential market reforms in Great Britain”, The Electricity Journal, 27(1): 66-73. 
Procter, R. (2013), "Integrating time-differentiated rates, demand response and smart grid to manage power system costs", The Electricity Journal, 26(3): 50-60. doi:10.1016/j.tej.2013.02.017.

Ramsey, F. 1927, “A contribution to the theory of taxation”, The Economic Journal, 37(145): 47-61.

Robinson, J. 1933. The Economics of Imperfect Competition, Macmillan, London.

Schmalensee, R. 1981. "Output and welfare implications of monopolistic third-degree price Discrimination”, American Economic Review, 71: 242-47.

Schwartz, M. 1986. "The perverse effects of the Robinson-Patman Act”, Antitrust Bulletin, Fall 1986, pp733-757.

Schwartz, M. 1990. "Third-degree price discrimination and output: Generalizing a welfare result". American Economic Review, 80: 1259-62.

Shaffer, G. \& Zhang, Z. 2000. "Pay to switch or pay to stay: Preference-based price discrimination in markets with switching costs”. Journal of Economics \& Management Strategy, 9:397-424.

Simshauser, P. 2014, "When does electricity price cap regulation become distortionary?", Australian Economic Review, 47(3): 304-323.

Simahauser, P. 2014b, "From first place to last: the National Electricity Market's policy-induced energy market death spiral”, Australian Economic Review, 47(4): 540-562.

Simshauser, P. 2016, "Distribution network prices and Solar PV: resolving rate instability and wealth transfers through demand tariffs", Energy Economics, 54(2016): 108-122.

Simshauser, P. \& Downer, D. 2016. "On the inequity of flat-rate electricity tariffs", The Energy Journal, 37(3): 199-229.

Simshauser, P. \& Nelson, T. 2015, “Australia's coal seam gas boom and the LNG entry result”, Australian Journal of Agricultural \& Resource Economics, 59(2015): 602-623.

Simshauser, P. \& Whish-Wilson, P. 2017, "Price discrimination in Australia's retail electricity markets: an analysis of Victoria and Southeast Queensland”, Energy Economics, 62(17): 92-103.

Simshauser, P. \& Tiernan, A. 2018, “Climate change policy discontinuity and its effects on Australia's National Electricity Market”, Australian Journal of Public Administration, article in-press.

Steiner, P. (1957), "Peak loads and efficient pricing", The Quarterly Journal of Economics, 71(4): 585610.

Stigler, G. 1987. A theory of price. New York: Macmillan.

Stigler, G. \& Friedland, C. 1962, "What can regulators regulate? The case of electricity", Journal of Law and Economics, 5(Oct 1962): 1-16.

Stole, L. 2007. "Price discrimination and competition”, In M. Armstrong and R. Porter (Eds.), Handbook of Industrial Economics, Vol. III, Elsevier, Amsterdam.

Taylor, C., 2003. "Supplier Surfing: Competition and Consumer Behaviour in Subscription Markets", Rand Journal of Economics, 34(2): 223-246.

Thisse, J.-F., and X. Vives, 1988: "On the Strategic Choice of Spatial Price Policy,” American Economic Review, 78(1): 122-137.

Tully, S. 2006, “The human right to access electricity”, The Electricity Journal, 19(3): 30-39.

Turvey, R. (1964), "Marginal cost pricing in practice”, Economica, 31(124): 426-432. do: $10.2307 / 2550523$.

Turvey, R. (1968). “Peak-Load Pricing”, Journal of Political Economy, 76(1): 101-113. 
Varian, H. 1985. "Price discrimination and social welfare", American Economic Review, 75: 870-75.

Varian, H. 1996. “Differential pricing and efficiency”. First Monday, 1(2):1-13.

Vickers, J. 2005, “Abuse of market power”, Economic Journal, 115(504): F244-F261.

Vickers, J. 2009, “Assessing undue discrimination, response to Ofgem consultation”, 1 May.

Waddams Price, C. and Zhu, M. 2013, "Pricing in the UK retail energy market, 2005-2013", Centre for Competition Policy Working Paper 13-12, University of East Anglia.

Waddams Price, C. \& Zhu, M., 2016. Non-discrimination clauses: their effect on British retail energy prices, The Energy Journal, 37(2): 111-132

Whinston, M. 1990, “Tying, Foreclosure and Exclusion,” American Economic Review, 80(4): 837859.

Wild, P., Bell, W.P. and Foster, J. 2015, "Impact of carbon prices on wholesale electricity prices and carbon pass-through rates in the Australian National Electricity Market", The Energy Journal, 36(3): 137-153.

Winter, R. 1997. “Colluding on relative prices”. RAND Journal of Economics, 28: 359-371.

Wenders, J. (1976), "Peak load pricing in the electric utility industry", Bell Journal of Economics, 7(1): 232-241. doi:10.2307/3003198.

Wood, L. and Faruqui, A. (2010), "Dynamic pricing and low-income customers", Public Utilities Fortnightly, November(2010): 60-64.

Yarrow, G. 2008, “The Impact of Maintaining Price Regulation”, Regulatory Policy Institute, Oxford, United Kingdom.

Yarrow, G. 2009, “Addressing undue discrimination: final proposals - Response to Ofgem's consultation”, 13 May 2009. 


\section{Research highlights}

Price dispersion is a central design feature of retail electricity markets.

In the household segment this can be perceived as unfair.

Queensland's fully regulated and deregulated retail markets are compared.

Price discrimination has been successful at regulating the average price.

Jawboning by the Department of Energy has helped to mitigate perceptions of fairness. 


\section{Accepted Manuscript}

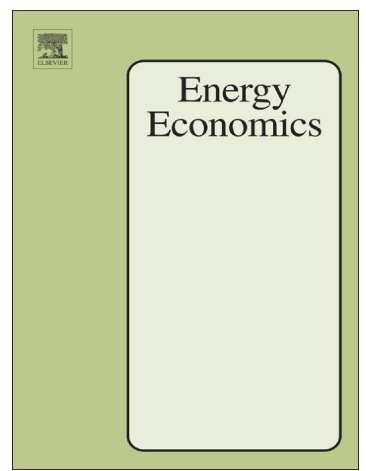

Paul Simshauser

PII:

S0140-9883(18)30303-7

DOI:

doi:10.1016/j.eneco.2018.08.007

Reference:

ENEECO 4120

To appear in:

Energy Economics

Received date:

10 March 2018

Revised date:

1 August 2018

Accepted date:

8 August 2018

Please cite this article as: Paul Simshauser, Price discrimination and the modes of failure in deregulated retail electricity markets. Eneeco (2018), doi:10.1016/j.eneco.2018.08.007

This is a PDF file of an unedited manuscript that has been accepted for publication. As a service to our customers we are providing this early version of the manuscript. The manuscript will undergo copyediting, typesetting, and review of the resulting proof before it is published in its final form. Please note that during the production process errors may be discovered which could affect the content, and all legal disclaimers that apply to the journal pertain. 